\title{
How Transnational Party Alliances Influence National Parties' Policies
}

\author{
Roman Senninger ${ }^{\dagger} \quad$ Daniel Bischof ${ }^{\ddagger} \quad$ Lawrence Ezrow ${ }^{\S}$
}

\begin{abstract}
Previous research reports that parties in established European democracies learn from and emulate the successful election strategies of foreign incumbents, i.e., successful parties are influential abroad. We theorize that - in addition to incumbency (or success) - exchange takes place through transnational party alliances in the European Union. Relying on party manifesto data and spatial econometric analyses, we show that belonging to the same European Parliament party group enhances learning and emulation processes between national political parties. Estimated short- and long-term effects are approximately two and three times greater when foreign incumbents are in the same European Parliament party group compared to other foreign incumbents. Our results have implications for our understanding of how transnational party groups influence national parties' policy positions.
\end{abstract}

\footnotetext{
${ }^{\dagger}$ Aarhus University; Corresponding author. Contact: rsenninger@ps.au.dk

‡University of Zurich

\$University of Essex
} 


\section{Introduction}

Anecdotal evidence suggests that domestic political parties learn from and emulate foreign parties - a process that has been labeled 'party policy diffusion'. A few examples include Tony Blair's 'New Labour' drawing inspiration from Clinton's 'New Democrat' campaign, the Danish Conservatives taking cues from the UK Conservative Party under Thatcher, and more recently, the German party Die Linke adopting policies from the Greek government party Syriza. Research on party competition generally focuses on domestic factors driving party behavior, like public opinion (see e.g. Adams et al., 2006), rival parties (see e.g. Meguid, 2005), voter transitions (Abou-Chadi and Stoetzer, 2020), and economic conditions (De Vries and Solaz, 2019), and more recent studies suggest that political parties emulate and learn from successful foreign parties as well (Böhmelt et al., 2016, 2017).

However, while the central finding of Böhmelt et al. $(2016,2017)$ that parties respond to foreign incumbent parties is important, the mechanism through which party policy diffusion occurs remains incomplete. Below we present theoretical and empirical arguments that exchanges between transnational party alliances in the European Parliament enhance party policy diffusion. The findings are important because they have implications for political representation and parties' election strategies. More specifically, they emphasize the role of transnational party alliances and (more generally) the European Union in explaining how the left-right policies of domestic political parties are influenced by foreign political parties.

\section{The Role of Transnational Party Alliances}

On first glance, the account that parties copy foreign incumbents as a heuristic to cope with uncertainty seems reasonable. But there is a large pool of foreign incumbents from which political parties could potentially learn, which suggests that there is considerable information to process in order for copying from foreign incumbents to occur. Surprisingly, recent studies do not find that domestic parties learn from and emulate foreign incumbent parties of the same party family. Peculiarly, this (non-)finding is at odds with findings in the literature on policy diffusion suggesting that governments are influenced by domestic and foreign governments - particularly from similar 
ideological camps (see e.g. Gilardi, 2010; Shipan and Volden, 2008). Furthermore, it goes against the anecdotal evidence that actually motivates current research on party policy diffusion.

We consider influential research about political parties in the European Union (EU) (Hix, 2002; Marsh and Norris, 1997) to theorize that party policy diffusion takes place through transnational party alliances at the EU level which are composed of representatives from national parties and provide an arena for inter-party exchange. Transnational party alliances have a special role in facilitating contact between national party representatives. They organize congresses and conferences which bring together prime ministers and party leaders to agree political strategies and resolutions.

Most centrally, transnational party representation in Europe takes place through the party groups in the European Parliament (EP) which have huge potential to facilitate party policy diffusion (Wolkenstein, Senninger and Bischof, 2020). Since the EP is one of the EU's co-legislators (together with the Council of the EU) a key task of party groups in the EP is to build and coordinate political majorities on legislation. To this end, groups generally convene during 'Group week' in Brussels where they prepare the upcoming plenary agenda. In addition, they also meet in Strasbourg during plenary week to (de-)brief parliamentary sittings. While the purpose of these meetings clearly serves the goal of having smooth and informed parliamentary processes, they are also used for, “[... ] development of Group positions on major political issues or debates or broader political strategy, and for receiving visiting delegations or leaders of national parties or other personalities" [emph. added] (Corbett, Jacobs and Shackleton, 2011, p.117).

Hence, meetings of transnational EP party groups go way beyond the work in the EP. They organize their own political activities which form an important channel of communication between national parties, as groups frequently welcome representatives from national parties, including ministers and front-bench parliamentarians. In addition, they often send delegations to national parties, organize seminars and conferences with national parties, and they publish brochures, studies, and newsletters aimed in part at national parties. A striking recent example is a meeting of the European Liberal Forum in April 2018 which brought together top-level representatives from liberal parties belonging to the EP party group ALDE "with the aim to equip politicians and staff members from liberal parties across Europe with concrete arguments and strategies on how to counter populistic and nationalistic tendencies” [emph. added] (European Liberal Forum, 2018). 
Representatives to the EP participating in events and meetings organized by the transnational EP party groups have regular contact to the national party and contribute to the position-taking of the national party just like parties' national parliamentary delegations and other factions (Gauja, 2013; Greene and O'Brien, 2016; Senninger and Bischof, 2018; Ceron, 2019).

EP party groups are not the only form of transnational party cooperation at the EU level. There are also European Parties ("Europarties") that are organized outside of the EP, but these are weak and depend almost entirely on the EP groups for funding and organizational staff (Kreppel, 2002). As a result, we suggest that transnational party policy diffusion is channeled through EP party groups and not Europarties. Belonging to transnational party groups in the EP also differs from belonging to party families because relations between parties in EP party groups are highly institutionalized and more active, and membership does not perfectly overlap, i.e., parties in the same party family do not automatically belong to the same EP party group. Therefore, EU membership, success in European elections, and strategic decisions about membership make transnational party alliances in the EP a much more important category for understanding party policy diffusion than party family.

In sum, institutionalized transnational party alliances in the European Parliament provide a channel through which parties observe, learn, and evaluate the successful election strategies of foreign incumbents:

Transnational Party Group Hypothesis: Political parties respond to the left-right policy position of foreign incumbents that recently belonged to the same European Parliament party group more than to other foreign incumbents.

\section{Research Design}

To test our hypothesis, we use time-series cross-sectional data from Böhmelt et al. (2016) that include 215 political parties from 26 Western European democracies for the time period from 19772010. ${ }^{1}$ The unit of analysis is a party-year.

To measure party's left-right position, we rely on the Comparative Manifesto Project data (MAR-

\footnotetext{
${ }^{1}$ These data cover EU member states from 1977 onwards, with additional data becoming available with the accession of new member states, and are also available for a few non-member states. Please consult Section $G$ in the Supplementary Information for a list of all parties.
} 
POR) (Volkens et al., 2014), which provides a measure of each party's general left-right placement (RILE). The original MARPOR variable ranges from -100 (extreme left) to +100 (extreme right). We use a linearly rescaled version of the response variable that ranges from 1 (extreme left) to 10 (extreme right). As information from MARPOR codes only election years, values from years between elections are missing. Therefore, each party's position between election years is assigned its value at the last election. ${ }^{2}$

Using party's left-right placement as our dependent variable we estimate spatio-temporal autoregressive models of the following form:

$$
y_{i t}=\phi y_{i t-1}+\beta \mathbf{x}_{i t-1}+\rho \mathbf{W} y_{i e-1}+\lambda_{i}+\tau_{t}+\epsilon_{i t}
$$

Where $y_{i t}$ is the dependent variable (RILE Party Position) for party i at time $t, y_{i t-1}$ signifies the (one year) temporally lagged dependent variable (Lagged RILE Party Position), $\mathbf{x}_{i t-1}$ is a vector of temporally lagged control variables as described in Böhmelt et al. (2016), $\lambda_{i}$ and $\tau_{t}$ are party and year-fixed effects respectively, and $\epsilon$ is the error term.

$\mathbf{W} y_{i e-1}$ is then the spatial lag variable that is the product of a spatial weights matrix $\mathbf{W}(\mathrm{NxNxT})$ that captures the relative connectivity of units $w_{i k}$ and a matrix $(\mathrm{NxT})$ of the time-lagged dependent variable of other units $k$. The time lag is constructed such that it considers positions of parties in the year before the last election held in their country. ${ }^{3}$ The approach considers that drafting manifestos is a "time-consuming process $[. .$.$] which typically takes place over a two-three year period during$ which party-affiliated research departments and committees draft sections of this manuscript, which are then circulated for revisions and approval upward to party elites and downward to activists" (Adams and Somer-Topcu, 2009, 832).

As described above, our decision to use a time-lagged spatial lag variable is theoretically motivated. However, under certain assumptions the approach also helps to avoid simultaneity bias of spatial ordinary least squares (S-OLS) (Beck, Gleditsch and Beardsley, 2006; Franzese and Hays, 2008b; Franzese, Hays and Cook, 2016). A central assumption is that interdependence does not

\footnotetext{
${ }^{2}$ Our results are robust to alternative approaches in which party positions between elections are interpolated using linear and spline interpolation (see Table S7 and S8).

${ }^{3}$ To illustrate this lag structure, assume that the political parties competing in the 2002 Dutch national election looked to the party position of the incumbent UK Labour Party. The previous inter-election period in the UK was 1997-2001. Thus, given our assumptions, Dutch parties relied on the 1997 Labour party position.
} 
occur instantaneously which in our study is probable due to the time-consuming process of drafting manifestos. In addition, parties' actions do not depend on foreign parties' expected actions. Instead parties are backward-looking (i.e., they look to what foreign incumbents have done in the past), again implying non-instantaneous interdependence. ${ }^{4}$

Even though the tools to empirically analyze interdependence between units have significantly developed in recent years (Anselin, 1988; Franzese and Hays, 2008a; Darmofal, 2015), challenges for empirical researchers still exist. First, one needs to distinguish interdependence from correlated responses to common shocks. Second, interdependence must be disentangled from temporal dynamics (Franzese and Hays, 2006, 2008b; Plümper and Neumayer, 2010).

We take different measures to reduce the possibility that what appears to be interdependence among political parties is actually the result of common exposure, and temporal dynamics (common trends) are addressed by adding a lagged dependent variable and year fixed effects. Further, party fixed effects hold unobserved variables constant. In addition to the above considerations, we account for public opinion and globalization. Including such relevant non-interdependent (domestic and unit-level, exogenous-external, and context-conditional) explanations is important. ${ }^{5}$ Failure to include the variables described above in the model leads to overestimating of the effects of interdependence.

\section{Defining Spatial Connectivity}

Based on our hypothesis, connectivity between our units of analysis is defined by incumbency status of the foreign party $\left(\right.$ party $\left._{k}\right)$ and parties' belonging to transnational alliances. The connectivity matrix ( $W$ Foreign Incumbent: Same party group) of this spatial lag variable is defined so that each element $W_{i, k, t}$ receives a value of 1 if $\operatorname{party}_{i}$ and party $y_{k}$ are not based in the same country, party $_{i}$ and party $y_{k}$ belong to the same EP party group and party $y_{k}$ was in government (or part of the governing coalition) during the year before the last election in its own system before time $\mathrm{t}$; and 0 otherwise. The data on parties' status indicating whether they are recent incumbents or not come from the ParlGov project (Döring and Manow, 2012). Transnational affiliations are obtained from

\footnotetext{
${ }^{4}$ In the appendix, we test for remaining temporal correlation in regression residuals.

${ }^{5}$ In the appendix, we also consider that parties might not respond equally to globalization (see Table S9).
} 
the Euromanifesto project (Braun et al., 2015). The Euromanifesto project covers all parties that gained representation in the EP and issued their own party manifesto (see Section F - Table S15).

To compare results from models that link parties that belong to the same EP party group with results from models that link parties that belong to different groups we create the following weight matrices. The connectivity matrix ( $W$ Foreign Incumbent: Different party group) captures links between parties and foreign incumbents that do not belong to the same transnational party alliance but are represented at the EU level. It is defined so that each element $W_{i, k, t}$ receives a value of 1 if party $_{i}$ and party $_{k}$ are not based in the same country, party $y_{i}$ and party $y_{k}$ belong to different party groups and party was in government (or part of the governing coalition) during the year before the last election in its own system before time t; and 0 otherwise. Finally, we created a spatial weights matrix to replicate the main finding by Böhmelt et al. (2016). The connectivity matrix ( $W$ Foreign Incumbent) is defined so that each element $W_{i, k, t}$ receives a value of 1 if party $y_{i}$ and party $y_{k}$ are not based in the same country, and party ${ }_{k}$ was in government (or part of the governing coalition) during the year before the last election in its own system before time $t$; and 0 otherwise.

\section{Empirical Results}

Model 1 (without controls) and Model 2 replicate earlier studies that conclude that foreign incumbent parties promote party policy diffusion (Böhmelt et al., 2016). The estimates on the spatial lag variable ( $\rho$ Foreign Incumbent) in our models are similarly positive and statistically significant, which is consistent with these previous findings. The remaining models turn to our hypothesis about the influence of transnational party groups. The spatial lag variable linking parties that belong to the same EP party group ( $\rho$ Foreign Incumbent: Same party group) is positive and statistically significant. The spatial lag variable linking parties that are not in the same EP party group but represented at the EU level ( $\rho$ Foreign Incumbent: Different party group) is positive, smaller in size, and not statistically significant. The spatial weights matrices are not row-standardized (Williams, 2015; Williams, Seki and Whitten, 2016), and, consequently, to estimate the short-term effects (i.e., first post-diffusion period effects) the coefficients of the spatial lags are multiplied by the average 
number of neighbors (Plümper and Neumayer, 2010). ${ }^{6}$

Each political party in the data has 22.29 neighbors, on average, that are foreign incumbents, and only 1.97 neighbors that are foreign incumbents and belong to the same party group. Also, each party has 7.82 neighbors that are foreign incumbents but belong to different party groups. Focusing on our first hypothesis, the short-term effect of foreign incumbents in the same party group is 0.003 (s.e. $=0.001)$. It is calculated from its rounded coefficient of 0.002 (Model 4) multiplied by the average number of neighbors. The coefficient size is comparable to findings in other research on party policy diffusion (Böhmelt et al., 2016).

Substantively, a party's left-right policy position would be 0.003 points farther to the right in the short run, if the two foreign incumbents (on average) in the same transnational party group shift one unit to the right, compared to the year before. For the second spatial lag variable (Foreign Incumbent: Different party group), if all foreign incumbents in different transnational party groups (that is eight on average) move to the right, the statistically insignificant effect would be 0.001 $($ s.e. $=0.002)$. The difference in the average number of foreign incumbents between the same transnational party group and other transnational party groups is quite large, and the implication of this difference is nontrivial. The fact that the short-term effect of foreign incumbents in the same party group outperforms the short-term effect of foreign incumbents in different party groups underscores the substantive importance of belonging to the same transnational party group: there are fewer parties leading to a greater overall effect on the focal party position. ${ }^{7}$

Since our model includes a temporally lagged variable (Lagged RILE Party Position) the coefficient estimates of the spatial lags only reflect short-term effects in a current year (Whitten, Williams and Wimpy, 2019). Therefore, we estimate asymptotic long-term effects for our spatial lag variables by considering the coefficient of our temporally lagged dependent variable (Plümper, Troeger and Manow, 2005; Plümper and Neumayer, 2010). The asymptotic long-term effects are shown in

\footnotetext{
${ }^{6}$ Row-standardization imposes the assumption that total exposure to the spatial stimulus is equal for all units $i$ (Neumayer and Plümper, 2016). We do not feel that this is a justifiable assumption. Without row-standardization, but with all-positive elements, the sign of rho is the sign of the contagion, but the size of rho cannot be interpreted directly. One reasonable option is to multiply the coefficient rho by the average element of the connectivity matrix (Plümper and Neumayer, 2010). The choice to not row standardize in this context is consistent with previous research (Williams, 2015; Williams, Seki and Whitten, 2016).

${ }^{7}$ We also compare results to foreign incumbents that are not represented in transnational party groups in Model 9 in the Supplementary Information (Section D \& E, Table S5 \& S6). We aslo rely on statistical simulation techniques in the Supplementary Information (Section B), and these analyses support our conclusion.
} 
Table 1: Single \& Multiple Spatial Lag Regression Models (S-OLS and MSTAR)

\begin{tabular}{|c|c|c|c|c|c|c|c|}
\hline \multicolumn{8}{|c|}{ Dependent variable: RILE Party Position } \\
\hline & Model 1 & Model 2 & Model 3 & Model 4 & Model 5 & Model 6 & Model 7 \\
\hline Lagged RILE Party Position & & $\begin{array}{c}0.751^{* * *} \\
(0.013)\end{array}$ & & $\begin{array}{c}0.749^{* * *} \\
(0.013)\end{array}$ & $\begin{array}{c}0.752^{* * *} \\
(0.013)\end{array}$ & $\begin{array}{c}0.749^{* * *} \\
(0.013)\end{array}$ & $\begin{array}{c}0.743^{* * *} \\
(0.012)\end{array}$ \\
\hline Lagged Median Voter & & $\begin{array}{c}0.501^{* * *} \\
(0.159)\end{array}$ & & $\begin{array}{c}0.453^{* * *} \\
(0.158)\end{array}$ & $\begin{array}{c}0.434^{* * *} \\
(0.158)\end{array}$ & $\begin{array}{c}0.450^{* * *} \\
(0.158)\end{array}$ & $\begin{array}{l}0.203^{* *} \\
(0.0 .88)\end{array}$ \\
\hline Lagged Economic Globalization & & $\begin{array}{c}0.032^{* * *} \\
(0.011)\end{array}$ & & $\begin{array}{c}0.029^{* *} \\
(0.011)\end{array}$ & $\begin{array}{c}0.027^{* *} \\
(0.011)\end{array}$ & $\begin{array}{c}0.029^{* *} \\
(0.011)\end{array}$ & $\begin{array}{c}0.010 \\
(0.007)\end{array}$ \\
\hline \multicolumn{8}{|l|}{ Lagged Median Voter * } \\
\hline Lagged Economic Globalization & & $\begin{array}{c}-0.007^{* * *} \\
(0.002)\end{array}$ & & $\begin{array}{c}-0.006^{* * *} \\
(0.002)\end{array}$ & $\begin{array}{c}-0.006^{* * *} \\
(0.002)\end{array}$ & $\begin{array}{c}-0.006^{* * *} \\
(0.002)\end{array}$ & $\begin{array}{c}-0.003^{* *} \\
(0.001)\end{array}$ \\
\hline$\rho$ Foreign Incumbent & $\begin{array}{c}0.004^{* *} \\
(0.002)\end{array}$ & $\begin{array}{c}0.004^{* * *} \\
(0.001)\end{array}$ & & & & & \\
\hline$\rho$ Foreign Incumbent: Same party group & & & $\begin{array}{c}0.005^{* * *} \\
(0.001)\end{array}$ & $\begin{array}{c}0.002^{* * *} \\
(0.001)\end{array}$ & & $\begin{array}{l}0.002^{* *} \\
(0.001)\end{array}$ & $\begin{array}{l}0.001^{*} \\
(0.001)\end{array}$ \\
\hline$\rho$ Foreign Incumbent: Different party group & & & & & $\begin{array}{c}0.0002 \\
(0.0003)\end{array}$ & $\begin{array}{c}0.0001 \\
(0.0003)\end{array}$ & \\
\hline Constant & $\begin{array}{c}4.128^{* * *} \\
(0.180)\end{array}$ & $\begin{array}{c}-1.562^{*} \\
(0.836)\end{array}$ & $\begin{array}{c}4.391^{* * *} \\
(0.152)\end{array}$ & $\begin{array}{l}-1.100 \\
(0.819)\end{array}$ & $\begin{array}{l}-1.005 \\
(0.820)\end{array}$ & $\begin{array}{l}-1.088 \\
(0.820)\end{array}$ & $\begin{array}{c}0.294 \\
(0.487)\end{array}$ \\
\hline Party Fixed Effects & $\checkmark$ & $\checkmark$ & $\checkmark$ & $\checkmark$ & $\checkmark$ & $\checkmark$ & $\checkmark$ \\
\hline Year Fixed Effects & $\checkmark$ & $\checkmark$ & $\checkmark$ & $\checkmark$ & $\checkmark$ & $\checkmark$ & $\checkmark$ \\
\hline Observations & 2,718 & 2,718 & 2,718 & 2,718 & 2,718 & 2,718 & 3,265 \\
\hline Adjusted $\mathrm{R}^{2}$ & 0.701 & 0.877 & 0.702 & 0.877 & 0.876 & 0.877 & 0.865 \\
\hline Residual Std. Error & 0.505 & 0.324 & 0.504 & 0.324 & 0.325 & 0.324 & 0.342 \\
\hline
\end{tabular}

Note: ${ }^{*} \mathrm{p}<0.1 ;{ }^{* *} \mathrm{p}<0.05 ;{ }^{* * *} \mathrm{p}<0.01$ 
Figure 1 (left panel).

If the two foreign incumbents in the same party group (on average) switch their left-right position by one, the long-term effect on a party is 0.013 (s.e. $=0.005)(0.29$ units on the original MARPOR scale). If all foreign incumbents in different party groups switch their left-right position by one, the effect on a party is 0.007 (s.e. $=0.009$ ), and this effect is insignificant. Also, Model 6 includes both spatial lag variables in a multiple spatial lag regression model, and it suggests that belonging to the same party group is a significant predictor of a party's policy position while belonging to a different party group is not. Model 7 shows results from a model in which the data is updated (1977-2016).

Figure 1: Temporal short-term and asymptotic long-term effects if foreign incumbents in the same party group and in different party groups shift their left-righ position by one
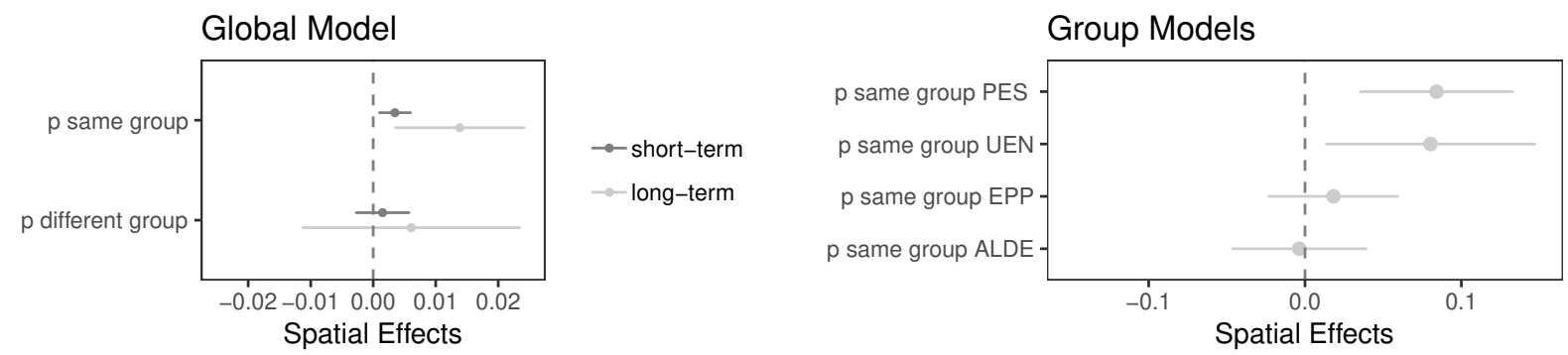

Note: PES=Social Democrats; EPP=European People's Party; ALDE=Liberals; UEN= Union for Europe of the Nations. The horizontal bars are 95 percent confidence intervals and the vertical dashed line represents a spatial effect of 0 . Estimates in the left panel are based on Models 4 and 5 in Table 1. Estimates in the right panel are based on the models in Table S3.

Finally, it might be that how party policy diffusion in the EP occurs varies across party groups. Specifically Social Democrats should be more inclined to adapt their policies to successful incumbent parties of their group as their efforts to exchange internationally is well known in the scholarly debate (Eley, 2002). To estimate heterogeneity across groups we show long-term effects from four models in which we disaggregate the weight matrices so that only parties within each EP group are connected with each other (Section A in the Supplementary Information). We do find a positive effect of EP group belonging across all groups other than the Liberals, which is consistent with the central findings of this study. Interestingly and in line with our priors discussed here, diffusion is strongest amongst parties belonging to the Social Democratic group. ${ }^{8}$ In contrast, results for models

\footnotetext{
${ }^{8}$ In the Supplementary Information (Section C) we show that party policy diffusion among Social Democratic Parties is particularly pronounced from the mid-1990s onwards providing evidence for the diffusion of 'third way' Social Democratic policies.
} 
in which we disaggregated the weight matrix so that all parties from the Social Democratic party family are connected with each other (see Table S4) provide no evidence for party policy diffusion. This underscores the important role of institutionalized party cooperation in the EP. ${ }^{9}$ Furthermore, the case of the UEN provides important evidence showing that foreign incumbents can influence the other parties from the same EP group even when the group has no long-standing history of cooperation beyond the EP. The finding is in line with recent studies on radical right and populist parties that emphasize that these parties increasingly collaborate through EP party groups (McDonnell and Werner, 2019).

\section{Conclusion}

Previous research finds that policies diffuse across national boundaries, and that political parties are influenced by foreign incumbent parties. Yet, this finding is at odds with anecdotal evidence about how parties may influence one another through transnational party families. Here, we shed light on the initial non-finding around party family, by showing that belonging to transnational party alliances in the EP provides a direct institutionalized channel for party policy diffusion. In addition, we show that party policy diffusion is particularly pronounced among Social Democratic parties, which suggests that the recent electoral success of the Danish and Spanish Social Democrats will in turn influence the policy platforms of foreign parties that belong to the same EP party group.

\footnotetext{
${ }^{9}$ We leverage differences in the timing of EU accession to provide evidence for our proposed mechanism of transnational party policy diffusion through EP party groups in the appendix (see Section 'Interrupted Time Series Analysis'). In addition, we extend our analyses to other dimensions of political conflict (see Section 'EU, Migration, and RILE Disaggregation').
} 


\section{References}

Abou-Chadi, Tarik and Lukas F. Stoetzer. 2020. "How Parties React to Voter Transitions." American Political Science Review 114:940-945.

Adams, James, Michael Clark, Lawrence Ezrow and Garrett Glasgow. 2006. "Are Niche Parties Fundamentally Different from Mainstream Parties? The Causes and the Electoral Consequences of Western European Parties' Policy Shifts, 1976-1998." American Journal of Political Science 50(3):513-529.

Adams, James and Zeynep Somer-Topcu. 2009. "Policy Adjustment by Parties in Response to Rival Parties' Policy Shifts: Spatial Theory and the Dynamics of Party Competition in Twenty-Five Post-War Democracies." British Journal of Political Science 39(4):825-846.

Anselin, Luc. 1988. Spatial Econometrics: Methods and Models. Dordrecht: Kluwer.

Beck, Nathaniel, Kristian Skrede Gleditsch and Kyle Beardsley. 2006. "Space Is More than Geography: Using Spatial Econometrics in the Study of Political Economy." International Studies Quarterly 50(1):27-44.

Böhmelt, Tobias, Lawrence Ezrow, Roni Lehrer and Hugh Ward. 2016. "Party Policy Diffusion." American Political Science Review 110(2):397-410.

Böhmelt, Tobias, Lawrence Ezrow, Roni Lehrer, Petra Schleiter and Hugh Ward. 2017. "Why Dominant Governing Parties Are Cross-Nationally Influential." International Studies Quarterly 61(4):749-759.

Braun, Daniela, Hermann Schmitt, Andreas M. Wüst, Sebastian Adrian Popa, Slava Mikhaylov and Felix Dwinger. 2015. "European Parliament Election Study 1979-2009, Euromanifesto Study. GESIS Data Archive, Cologne. ZA5102 Data file Version 1.1.0.”.

Ceron, Andrea. 2019. Leaders, Factions and the Game of Intra-Party Politics. Routledge.

Corbett, Richard, Francis Jacobs and Michael Shackleton. 2011. The European Parliament. London: John Harper.

Darmofal, David. 2015. Spatial Analysis for the Social Sciences. Cambridge: Cambridge University Press.

De Vries, Catherine E. and Hector Solaz. 2019. "Sweeping It Under the Rug: How Government Parties Deal with Deteriorating Economic Conditions.” Party Politics 25(1):63-75.

Döring, Holger and Philip Manow. 2012. "Parliament and government composition database (ParlGov): An infrastructure for empirical information on parties, elections and governments in modern democracies.".

Eley, Geoff. 2002. Forging Democracy: The History of the Left in Europe, 1850-2000. Oxford University Press.

European Liberal Forum, (ELF). 2018. A Liberal European Leadership after 2019. ELF: Stockholm.

Franzese, Robert J. and Jude C. Hays. 2006. "Strategic Interaction among EU Governments in Active Labor Market Policy-making: Subsidiarity and Policy Coordination under the European Employment Strategy.” European Union Politics 7(2):167-189. 
Franzese, Robert J. and Jude C. Hays. 2008a. Empirical Models of Spatial Dependence. In Oxford Handbook of Political Methodology, ed. Janet M. Box-Steffensmeier, Henry E. Brady and David Collier. Oxford: Oxford University Press pp. 570-604.

Franzese, Robert J. and Jude C. Hays. 2008b. "Interdependence in Comparative Politics - Substance, Theory, Empirics, Substance.” Comparative Political Studies 41(4-5):742-780.

Franzese, Robert J., Jude C. Hays and Scott J. Cook. 2016. "Spatial- and SpatiotemporalAutoregressive Probit Models of Interdependent Binary Outcomes." Political Science Research and Methods 4(1):151-173.

Gauja, Anika. 2013. The Politics of Party Policy. Palgrave Macmillan.

Gilardi, Fabrizio. 2010. "Who Learns from What in Policy Diffusion Processes?” American Journal of Political Science 54(3):650-666.

Greene, Zachary and Diana Z. O’Brien. 2016. "Diverse Parties, Diverse Agendas? Female Politicians and the Parliamentary Party's Role in Platform Formation." European Journal of Political Research 55(3):435-453.

Hix, Simon. 2002. "Parliamentary Behavior with Two Principals: Preferences, Parties, and Voting in the European Parliament." American Journal of Political Science 46(3):688-698.

Kreppel, Amie. 2002. The European Parliament and Supranational Party System. Cambridge University Press.

Marsh, Michael and Pippa Norris. 1997. "Political Representation in the European Parliament." European Journal of Political Research 32(2):153-164.

McDonnell, Duncan and Annika Werner. 2019. International Populism: The Radical Right in the European Parliament. Oxford University Press.

Meguid, Bonnie M. 2005. "Competition Between Unequals: The Role of Mainstream Party Strategy in Niche Party Success." American Political Science Review 99(3):347-359.

Neumayer, Eric and Thomas Plümper. 2016. "W." Political Science Research and Methods 4(1):175-193.

Plümper, Thomas and Eric Neumayer. 2010. "Model Specification in the Analysis of Spatial Dependence." European Journal of Political Research 49(3):418-442.

Plümper, Thomas, Vera E. Troeger and Philip Manow. 2005. "Panel Data Analysis in Comparative Politics: Linking Method to Theory." European Journal of Political Research 44(2):327-354.

Senninger, Roman and Daniel Bischof. 2018. "Working in Unison: Political Parties and Policy Issue Transfer in the Multilevel Space.” European Union Politics 19(1):140-162.

Shipan, Charles R. and Craig Volden. 2008. "The Mechanisms of Policy Diffusion." American Journal of Political Science 52(4):840-857.

Volkens, Andrea, Pola Lehmann, Nicolas Merz, Sven Regel and Annika Werner. 2014. The Manifesto Data Collection. Manifesto Project (MRG/CMP/MARPOR). Version 2014b. Berlin: Wissenschaftszentrum Berlin für Sozialforschung. 
Ward, Hugh, Lawrence Ezrow and Han Dorussen. 2011. "Globalization, Party Positions, and the Median Voter." World Politics 63(03):509-547.

Whitten, Guy D., Laron K. Williams and Cameron Wimpy. 2019. "Interpretation: The Final Spatial Frontier.” Political Science Research \& Methods p. forthcoming.

Williams, Laron K. 2015. "It's All Relative: Spatial Positioning of Parties and Ideological Shifts." European Journal of Political Research 54(1):141-159.

Williams, Laron K., Katsunori Seki and Guy D. Whitten. 2016. "You've Got Some Explaining To Do: The Influence of Economic Conditions and Spatial Competition on Party Strategy." Political Science Research and Methods 4(1):47-63.

Wolkenstein, Fabio, Roman Senninger and Daniel Bischof. 2020. "Party Policy Diffusion in the European Multilevel Space: What It Is, How It Works, and Why It Matters." Journal of Elections, Public Opinion and Parties 30(3):339-357. 


\section{Supplementary Information}

\section{A - Group Models: Spatial Weight Matrices and Regression Ta- bles}

To estimate the group models presented in Figure 1 (right panel) we consider disaggregated links between individual transnational party alliances. The first one ( $W$ Foreign Incumbent: same group PES) is defined so that each element $W_{i, k, t}$ receives a value of 1 if party $_{i}$ and party $y_{k}$ are not based in the same country, party $y_{i}$ and party $_{k}$ belong to the Social Democratic transnational party alliance (PES) and party $y_{k}$ was in government (or part of the governing coalition) during the year before the last election in its own system before time $t$. Second, ( $W$ Foreign Incumbent: same group EPP) is defined so that each element $W_{i, k, t}$ receives a value of 1

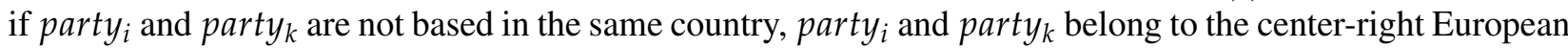
People's Party transnational party alliance and party $_{k}$ was in government (or part of the governing coalition) during the year before the last election in its own system before time $t$. Third, ( $W$ Foreign Incumbent: same group ALDE) is defined so that each element $W_{i, k, t}$ receives a value of 1 if party $y_{i}$ and party $y_{k}$ are not based

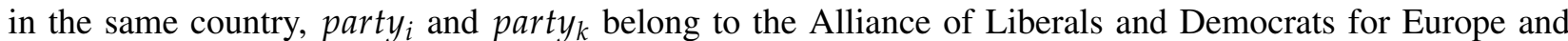
party $_{k}$ was in government (or part of the governing coalition) during the year before the last election in its own system before time $t$. Finally, ( $W$ Foreign Incumbent: same group UEN) is defined so that each element $W_{i, k, t}$ receives a value of 1 if party $y_{i}$ and party $y_{k}$ are not based in the same country, party $y_{i}$ and party belong $_{k}$ to the Union for Europe of the Nations and party was $_{\text {in }}$ in government (or part of the governing coalition) during the year before the last election in its own system before time $t$. The average number of neighbors for each of the four spatial weights matrices is shown in Table S2.

Table S 2: Average number of neighbors for disaggregated spatial weights matrices

\begin{tabular}{lc} 
Spatial lag variable & neighbors \\
\cline { 1 - 1 }$\rho$ Foreign Incumbent: Same group PES & 6.2 \\
$\rho$ Foreign Incumbent: Same group EPP & 4.1 \\
$\rho$ Foreign Incumbent: Same group ALDE & 3.3 \\
$\rho$ Foreign Incumbent: Same group UEN & 0.4
\end{tabular}


Table S 3: Single 'disaggregated' Spatial Lag Regression Models (S-OLS)

\begin{tabular}{|c|c|c|c|c|}
\hline & \multicolumn{4}{|c|}{ Dependent variable: RILE Party Position } \\
\hline & Model D1 & Model D2 & Model D3 & Model D4 \\
\hline Lagged RILE Party Position & $\begin{array}{c}0.746^{* * *} \\
(0.013)\end{array}$ & $\begin{array}{c}0.752^{* * *} \\
(0.013)\end{array}$ & $\begin{array}{c}0.752^{* * *} \\
(0.013)\end{array}$ & $\begin{array}{c}0.750^{* * *} \\
(0.013)\end{array}$ \\
\hline Lagged Median Voter & $\begin{array}{c}0.454^{* * *} \\
(0.158)\end{array}$ & $\begin{array}{c}0.438^{* * *} \\
(0.158)\end{array}$ & $\begin{array}{c}0.437^{* * *} \\
(0.158)\end{array}$ & $\begin{array}{c}0.410^{* * *} \\
(0.158)\end{array}$ \\
\hline Lagged Economic Globalization & $\begin{array}{c}0.029^{* *} \\
(0.011)\end{array}$ & $\begin{array}{c}0.028^{* *} \\
(0.011)\end{array}$ & $\begin{array}{c}0.027^{* *} \\
(0.011)\end{array}$ & $\begin{array}{c}0.026^{* *} \\
(0.011)\end{array}$ \\
\hline Lagged Median Voter $*$ & & & & \\
\hline Lagged Economic Globalization & $\begin{array}{c}-0.006^{* * *} \\
(0.002)\end{array}$ & $\begin{array}{c}-0.006^{* * *} \\
(0.002)\end{array}$ & $\begin{array}{c}-0.006^{* * *} \\
(0.002)\end{array}$ & $\begin{array}{c}-0.005^{* * *} \\
(0.002)\end{array}$ \\
\hline$\rho$ Foreign Incumbent: Same group PES & $\begin{array}{c}0.003^{* * *} \\
(0.001)\end{array}$ & & & \\
\hline$\rho$ Foreign Incumbent: Same group EPP & & $\begin{array}{c}0.001 \\
(0.001)\end{array}$ & & \\
\hline$\rho$ Foreign Incumbent: Same group ALDE & & & $\begin{array}{c}-0.0003 \\
(0.002)\end{array}$ & \\
\hline$\rho$ Foreign Incumbent: Same group UEN & & & & $\begin{array}{c}0.054^{* *} \\
(0.023)\end{array}$ \\
\hline Constant & $\begin{array}{l}-1.074 \\
(0.818)\end{array}$ & $\begin{array}{l}-1.021 \\
(0.820)\end{array}$ & $\begin{array}{l}-1.016 \\
(0.820)\end{array}$ & $\begin{array}{l}-0.856 \\
(0.822)\end{array}$ \\
\hline Observations & 2,718 & 2,718 & 2,718 & 2,718 \\
\hline $\mathrm{R}^{2}$ & 0.888 & 0.888 & 0.888 & 0.888 \\
\hline Adjusted $\mathrm{R}^{2}$ & 0.877 & 0.876 & 0.876 & 0.877 \\
\hline F Statistic $(\mathrm{df}=252 ; 2465)$ & $77.802^{* * *}$ & $77.402^{* * *}$ & $77.403^{* * *}$ & $77.597^{* * *}$ \\
\hline
\end{tabular}


Table S 4: Single Spatial Lag Regression Models (S-OLS)

\begin{tabular}{|c|c|c|}
\hline & \multicolumn{2}{|c|}{ Dependent variable: } \\
\hline & \\
\hline & Model 1 & Model 2 \\
\hline Lagged RILE Party Position & $\begin{array}{c}0.751^{* * *} \\
(0.013)\end{array}$ & $\begin{array}{c}0.751^{* * *} \\
(0.013)\end{array}$ \\
\hline Lagged Median Voter & $\begin{array}{c}0.438^{* * *} \\
(0.158)\end{array}$ & $\begin{array}{c}0.434^{* * *} \\
(0.158)\end{array}$ \\
\hline Lagged Economic Globalization & $\begin{array}{l}0.028^{* *} \\
(0.011)\end{array}$ & $\begin{array}{l}0.027^{* *} \\
(0.011)\end{array}$ \\
\hline \multicolumn{3}{|l|}{ Lagged Median Voter * } \\
\hline Lagged Economic Globalization & $\begin{array}{c}-0.006^{* * *} \\
(0.002)\end{array}$ & $\begin{array}{c}-0.006^{* * *} \\
(0.002)\end{array}$ \\
\hline$\rho$ Foreign: Same party family Social Democrats & $\begin{array}{l}0.00001 \\
(0.0002)\end{array}$ & \\
\hline$\rho$ Foreign Incumbent: Same party family Social Democrats & & $\begin{array}{l}-0.0003 \\
(0.0004)\end{array}$ \\
\hline Constant & $\begin{array}{l}-1.021 \\
(0.820)\end{array}$ & $\begin{array}{l}-1.007 \\
(0.820)\end{array}$ \\
\hline Observations & 2,718 & 2,718 \\
\hline $\mathrm{R}^{2}$ & 0.888 & 0.888 \\
\hline Adjusted $\mathrm{R}^{2}$ & 0.876 & 0.876 \\
\hline Residual Std. Error $(d f=2465)$ & 0.325 & 0.325 \\
\hline F Statistic & $77.402^{* * *}$ & $77.418^{* * *}$ \\
\hline
\end{tabular}

To compare the results of the disaggregated model for the Social Democratic transnational group in the EP with the Social Democratic party family, we created to additional weight matrices. The first one (W Foreign: Same party family Social Democrats) is defined so that each element $W_{i, k, t}$ receives a value of 1 if

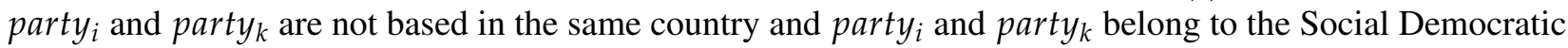
party family (as coded according to the MARPOR data). Second, ( $W$ Foreign Incumbent: Same party family Social Democrats) is defined so that each element $W_{i, k, t}$ receives a value of 1 if party $y_{i}$ and party $y_{k}$ are not based in the same country and party $y_{i}$ and party $y_{k}$ belong to the Social Democratic party family (as coded according to the MARPOR data) and party $y_{k}$ was in government (or part of the governing coalition) during the year before the last election in its own system before time $t$.

\section{B - Simulations}

We estimate the parameters of Model 4 and Model 5 (Table 1) and draw 1000 sets of simulated coefficients from their posterior distribution. Next, we fix the spatial lag variables ( $\rho$ Foreign Incumbent: Same group and $\rho$ Foreign Incumbent: Different group) at the fifth (0.00 and 0.00) and ninety-fifth percentile (47.39 and 129.97) holding all other variables at their means, and then 1000 expected values of the RILE Party Position are calculated. Figure S2 shows the distributions of simulated expected values. In the left panel, we observe differences in expected values of the RILE Party Position depending on whether the values of the spatial lag variable ( $\rho$ Foreign Incumbent: Same group) are low or high. The means of the two distributions are different from each other at conventional levels of statistical significance. In contrast, we observe no differences in expected values of the RILE Party Position depending on whether the values of the spatial lag variable ( $\rho$ Foreign Incumbent: Different group) are low or high. The two distributions are not different from each other at conventional levels of statistical significance. This indicates that the positions of incumbent parties within the same group will influence a focal party, while the positions of incumbent parties in other 
groups do not. In addition, we calculated first differences between the two expected values and it shows that in 894 out of 1000 simulations the expected value based on the parties from the same party group is larger than the expected value based on the different party group. Thus the effect of (on average) two incumbent parties within the same party group is larger than the effect of (on average) nearly eight parties in other party groups.

Figure S 2: Simulated expected values of RILE Party Position
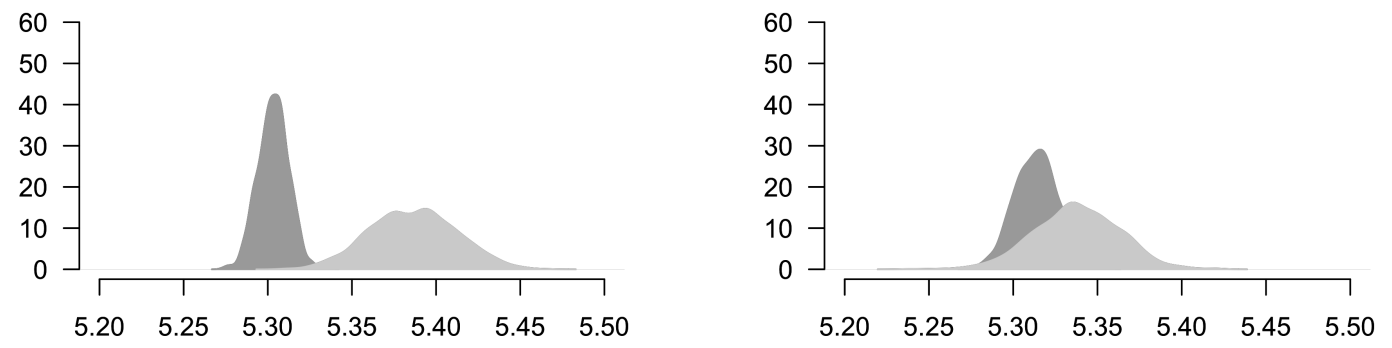

Note: The plot shows the distribution of a focal party's expected RILE position on the x-axis, based on simulations fixing the spatial lag variables at the fifth (dark gray) and ninety-fifth percentile (light gray). The $y$-axis indicates the number of simulations. Left panel: Same group. Right panel: Different group. The left panel (for same party group) shows that left-right positions of a focal party are more strongly influenced, i.e., pulled further to the left or right, by foreign incumbents in the same transnational group, when compared to the effects simulated in the right panel for foreign incumbents that are not in the same transnational group.

\section{C- Equilibrium Effects}

In the global model but also in the disaggregated group models, party policy diffusion is indicated by the spatial parameter $\rho$. It reflects changes in the left-right position of parties based on changes in the timelagged left-right position of foreign incumbents belonging to the same transnational party group. Crucially, it does not provide information about specific diffusion patterns of individual parties (Whitten, Williams and Wimpy, 2019). To provide such insights, we re-analyze the impact of changes in the time-lagged leftright position of Social Democratic incumbent parties on individual parties using equilibrium impacts (Ward and Skrede Gleditsch 2008). In particular, we estimate differences in predicted values of parties' left-right position between Model 4 (global model) in Table 1 and a model in which the value of the time-lagged left-right position of Social Democratic incumbent parties is increased by 1. Figure S3 shows the changes in predicted values for the five parties with the largest positive differences in predicted values between the two models in the short term. In addition, it indicates whether the top five parties belong to the Social Democratic transnational party alliance or not. The figure shows that it was not always the case that Social Democratic parties learn and emulate the position of Social Democratic foreign incumbents the most. Only from the 1990's onwards, we observe that parties within the same transnational party alliance are learning and emulating the position of Social Democratic foreign incumbents the most. This suggests that withingroup party policy diffusion in the Social Democratic transnational party alliance was particularly pronounced during the implementation of 'third way' policies. Interestingly, in the period from 2004-2006 we observe that radical-right parties such as the Austrian Freedom Party learn and emulate the policy positions of Social Democratic foreign incumbent parties most strongly. 
Figure S 3: Differences in predicted RILE values (top five parties)
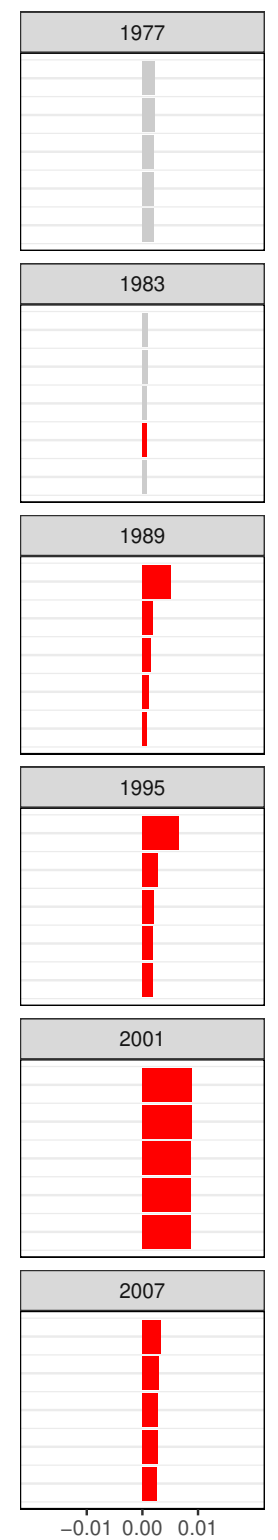
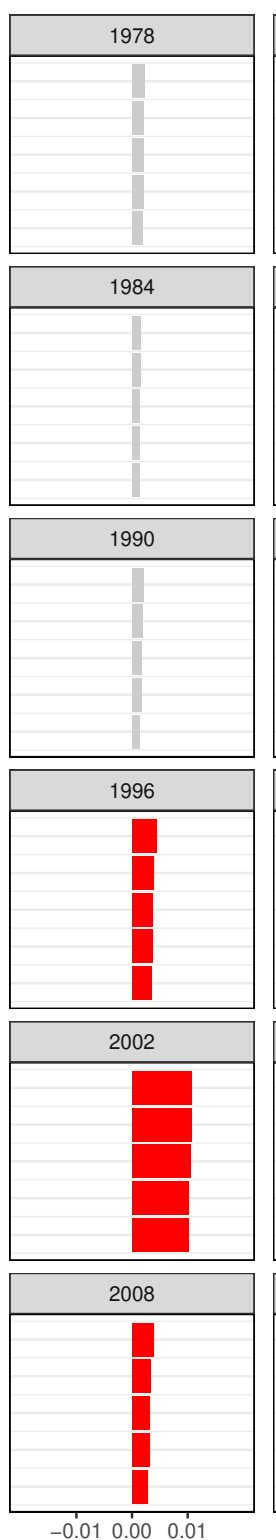
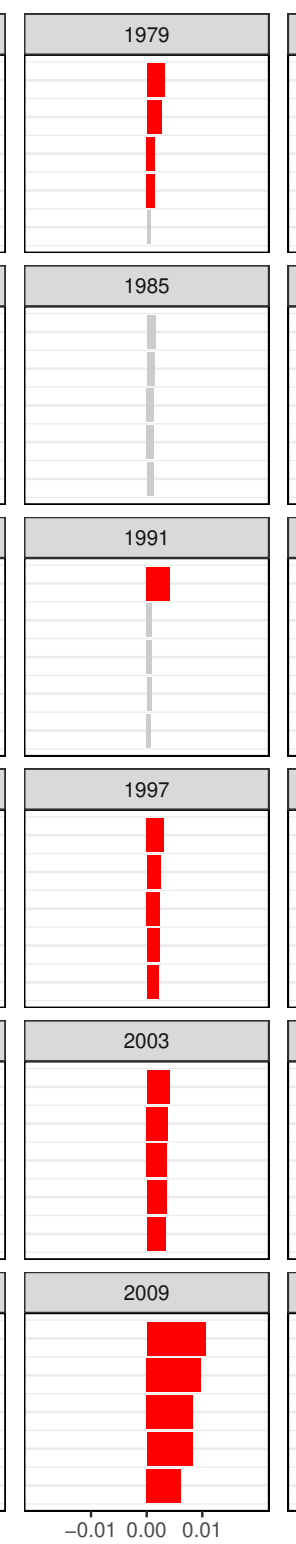
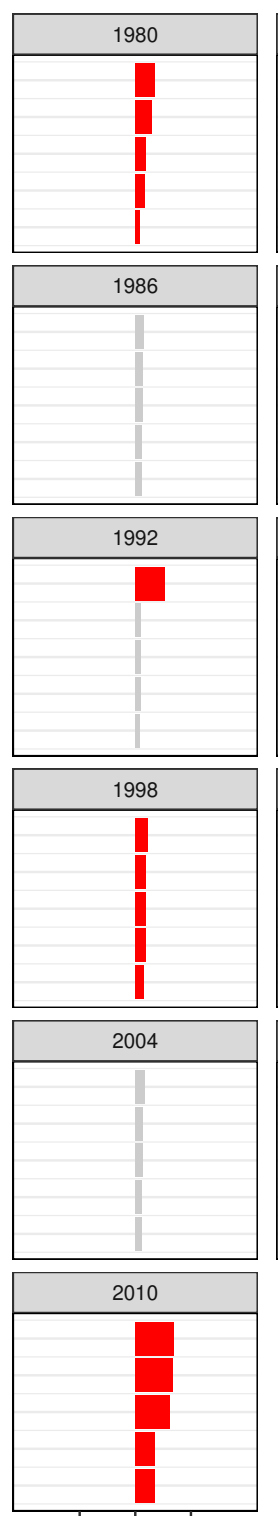

$\begin{array}{lll}-0.01 & 0.00 & 0.01\end{array}$
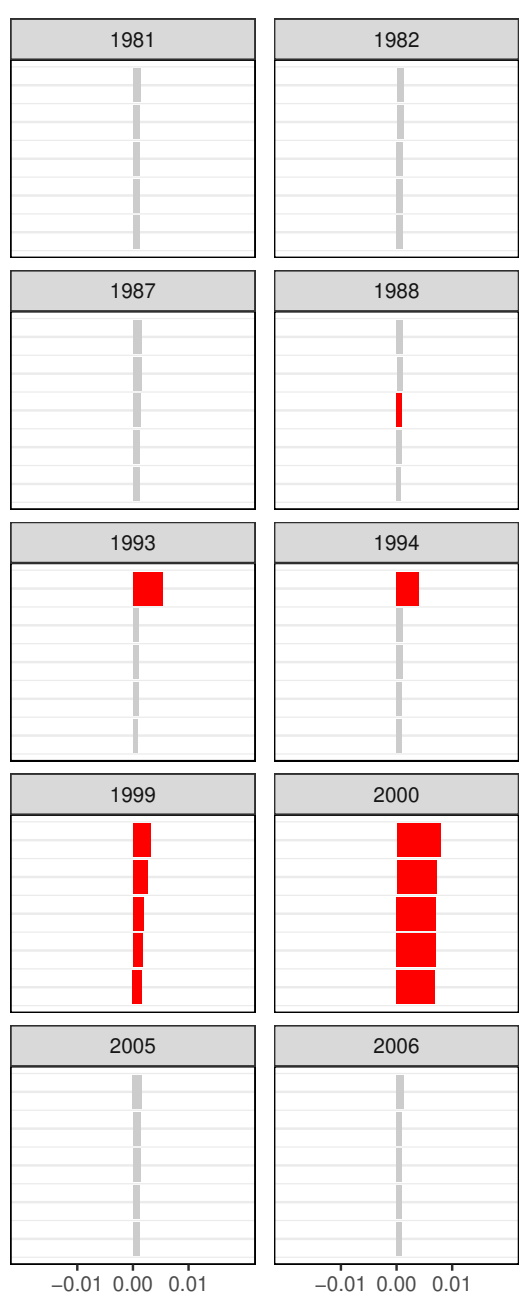

Member of Social Democratic Transnational Party Group

no

\section{D - Additional Spatial Weights Matrices}

The two matrices ( $W$ Foreign Incumbent: Same Party Group and $W$ Foreign Incumbent: Different Party Group) described in the main part of the manuscript connect parties that are represented at the EU level and affiliated with a transnational party group. However, there are further links between parties to explore where either party $_{i}$ or the foreign incumbent party $k$ is not affiliated/represented at the European level. As previously mentioned, each focal party has on average 22.29 neighbors. Leaving aside, the 1.97 neighbors in the same transnational group and 7.82 neighbors in different groups there are around 12 neighbors left representing situations where either party $i$ or the foreign incumbent party $y_{k}$ is not affiliated/represented at the European level. To consider links between parties that are represented and affiliated at the EU level and parties that are not represented and affiliated at the EU level, we construct the following additional connectivity matrices. The first one ( $W$ Foreign Incumbent: $\operatorname{party}_{i} \& \operatorname{party}_{k}$ not affiliated/represented) is 
defined so that each element $W_{i, k, t}$ receives a value of 1 if party $y_{i}$ and party $y_{k}$ are not based in the same country, party $y_{i}$ and party $_{k}$ are not affiliated to a group or not represented at the EU level and party $y_{k}$ was in government (or part of the governing coalition) during the year before the last election in its own system before time $t$. Second, ( $W$ Foreign Incumbent: party $y_{i}$ not affiliated/represented) is defined so that each element $W_{i, k, t}$ receives a value of 1 if party $y_{i}$ and party $_{k}$ are not based in the same country, only party $y_{i}$ is not affiliated to a group or not represented at the EU level and party $k$ was in government (or part of the governing coalition) during the year before the last election in its own system before time $t$. Third, ( $W$ Foreign Incumbent: party $_{k}$ not affiliated/represented) is defined so that each element $W_{i, k, t}$ receives a value

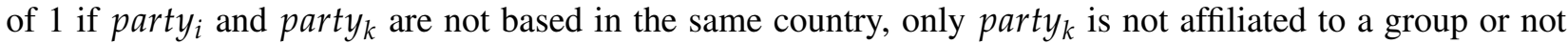
represented at the EU level and party was $_{\text {in }}$ government (or part of the governing coalition) during the year before the last election in its own system before time $t$. The average number of neighbors for each of the three spatial weights matrices is shown in table S3.

Table S 5: Average number of neighbors for additional spatial weights matrices

Spatial lag variable

neighbors

$\rho$ Foreign Incumbent: party $_{i} \&$ party $_{k}$ not affiliated/represented

$\rho$ Foreign Incumbent: party $_{i}$ not affiliated/represented

6.85

$\rho$ Foreign Incumbent: party $_{k}$ not affiliated/represented

2.93

\section{E - Additional Empirical Results}

The coefficients of spatial lag variables considering non-affiliated and non-represented parties further substantiate the important role of being represented at the EU level in order to learn from and emulate foreign incumbent parties (Table S4). The coefficient $\rho$ Foreign Incumbent: party \& $_{i}$ party $y_{k}$ not affiliated/represented is negatively signed and statistically significant at conventional levels which indicates that parties that are not represented at the EU level or affiliated to a party group do not learn from and emulate each other but instead move further apart in their RILE position. Similarly, the coefficient $\rho$ Foreign Incumbent: party not affiliated/represented indicates that parties that are not represented at the EU level or affiliated to a party group do not learn from and emulate foreign incumbents that are represented at the EU level and affiliated to a party group. Finally, the coefficient $\rho$ Foreign Incumbent: party $y_{k}$ not affiliated/represented, statistically significant at conventional levels, indicates that parties represented at the EU level and affiliated to a group observe and respond to foreign incumbent parties that are not represented at the EU level or not affiliated to a party group. This suggests that parties that are represented and affiliated at the EU level consider additional channels. However, considering the short-term and long-term effect of the spatial lag based on shifts in left-right positions of (on average) three foreign incumbents we see that learning from foreign incumbents that belong to the same transnational party group outweighs learning from foreign incumbents that are not represented at the EU level. 
Table S 6: Single Spatial Lag Regression Models (S-OLS)

\begin{tabular}{|c|c|c|c|}
\hline & \multicolumn{3}{|c|}{ Dependent variable: RILE Party Position } \\
\hline & Model A1 & Model A2 & Model A3 \\
\hline Lagged RILE Party Position & $\begin{array}{c}0.751^{* * *} \\
(0.013)\end{array}$ & $\begin{array}{c}0.752^{* * *} \\
(0.013)\end{array}$ & $\begin{array}{c}0.751^{* * *} \\
(0.013)\end{array}$ \\
\hline Lagged Median Voter & $\begin{array}{c}0.440^{* * *} \\
(0.158)\end{array}$ & $\begin{array}{c}0.432^{* * *} \\
(0.158)\end{array}$ & $\begin{array}{c}0.448^{* * *} \\
(0.158)\end{array}$ \\
\hline Lagged Economic Globalization & $\begin{array}{c}0.028^{* *} \\
(0.011)\end{array}$ & $\begin{array}{c}0.027^{* *} \\
(0.011)\end{array}$ & $\begin{array}{c}0.029^{* *} \\
(0.011)\end{array}$ \\
\hline Lagged Median Voter * & & & \\
\hline Lagged Economic Globalization & $\begin{array}{c}-0.006^{* * *} \\
(0.002)\end{array}$ & $\begin{array}{c}-0.006^{* * *} \\
(0.002)\end{array}$ & $\begin{array}{c}-0.006^{* * *} \\
(0.002)\end{array}$ \\
\hline$\rho$ Foreign Incumbent: party $_{i} \&$ party $_{k}$ not affiliated/represented & $\begin{array}{c}-0.001^{*} \\
(0.001)\end{array}$ & & \\
\hline$\rho$ Foreign Incumbent: party $_{i}$ not affiliated/represented & & $\begin{array}{c}-0.0002 \\
(0.0002)\end{array}$ & \\
\hline$\rho$ Foreign Incumbent: party $_{k}$ not affiliated/represented & & & $\begin{array}{l}0.001^{*} \\
(0.001)\end{array}$ \\
\hline Constant & $\begin{array}{c}-0.992 \\
(0.820)\end{array}$ & $\begin{array}{l}-1.001 \\
(0.820)\end{array}$ & $\begin{array}{c}-1.083 \\
(0.820)\end{array}$ \\
\hline Party Fixed Effects & $\checkmark$ & $\checkmark$ & $\checkmark$ \\
\hline Year Fixed Effects & $\sqrt{ }$ & $\checkmark$ & $\checkmark$ \\
\hline Observations & 2,718 & 2,718 & 2,718 \\
\hline Adjusted $\mathrm{R}^{2}$ & 0.876 & 0.876 & 0.876 \\
\hline F Statistic & $77.507^{* * *}$ & $77.438^{* * *}$ & $77.519^{* * *}$ \\
\hline
\end{tabular}

Note: ${ }^{*} \mathrm{p}<0.1 ;{ }^{* *} \mathrm{p}<0.05 ;{ }^{* * *} \mathrm{p}<0.01$ 
Table S 7: Single Spatial Lag Regression Models (S-OLS)

\begin{tabular}{|c|c|c|c|c|}
\hline & \multicolumn{4}{|c|}{ Dependent variable: RILE Party Position } \\
\hline & Model LI1 & Model LI2 & Model LI3 & Model LI4 \\
\hline Lagged RILE Party Position & & $\begin{array}{c}0.827^{* * *} \\
(0.010)\end{array}$ & & $\begin{array}{c}0.828^{* * *} \\
(0.010)\end{array}$ \\
\hline Lagged Median Voter & & $\begin{array}{c}0.389^{* * *} \\
(0.114)\end{array}$ & & $\begin{array}{c}0.326^{* * *} \\
(0.114)\end{array}$ \\
\hline Lagged Economic Globalization & & $\begin{array}{c}0.024^{* * *} \\
(0.008)\end{array}$ & & $\begin{array}{l}0.019^{* *} \\
(0.008)\end{array}$ \\
\hline \multicolumn{5}{|l|}{ Lagged Median Voter* } \\
\hline Lagged Economic Globalization & & $\begin{array}{c}-0.005^{* * *} \\
\quad(0.002)\end{array}$ & & $\begin{array}{c}-0.004^{* * *} \\
(0.002)\end{array}$ \\
\hline$\rho$ Foreign Incumbent & $\begin{array}{c}0.006^{* * *} \\
(0.002)\end{array}$ & $\begin{array}{c}0.004^{* * *} \\
(0.001)\end{array}$ & & \\
\hline$\rho$ Foreign Incumbent: Same party group & & & $\begin{array}{c}0.004^{* * *} \\
(0.001)\end{array}$ & $\begin{array}{l}0.001^{* *} \\
(0.0005)\end{array}$ \\
\hline Constant & $\begin{array}{c}5.724^{* * *} \\
(0.213)\end{array}$ & $\begin{array}{c}-1.109^{*} \\
(0.603)\end{array}$ & $\begin{array}{c}6.118^{* * *} \\
(0.197)\end{array}$ & $\begin{array}{l}-0.555 \\
(0.593)\end{array}$ \\
\hline Party Fixed Effects & $\checkmark$ & $\checkmark$ & $\checkmark$ & $\checkmark$ \\
\hline Year Fixed Effects & $\checkmark$ & $\checkmark$ & $\checkmark$ & $\checkmark$ \\
\hline Observations & 2,718 & 2,718 & 2,718 & 2,718 \\
\hline Adjusted $\mathrm{R}^{2}$ & 0.746 & 0.932 & 0.747 & 0.931 \\
\hline F Statistic & $33.208^{* * *}$ & $147.932^{* * *}$ & $33.289^{* * *}$ & $146.717^{* * *}$ \\
\hline
\end{tabular}

Table S 8: Single Spatial Lag Regression Models (S-OLS)

\begin{tabular}{|c|c|c|c|c|}
\hline & \multicolumn{4}{|c|}{ Dependent variable: RILE Party Position } \\
\hline & Model SI1 & Model SI2 & Model SI3 & Model SI4 \\
\hline Lagged RILE Party Position & & $\begin{array}{c}0.822^{* * *} \\
(0.012)\end{array}$ & & $\begin{array}{c}0.822^{* * *} \\
(0.012)\end{array}$ \\
\hline Lagged Median Voter & & $\begin{array}{l}0.275^{*} \\
(0.146)\end{array}$ & & $\begin{array}{c}0.209 \\
(0.145)\end{array}$ \\
\hline Lagged Economic Globalization & & $\begin{array}{l}0.017^{*} \\
(0.010)\end{array}$ & & $\begin{array}{c}0.012 \\
(0.010)\end{array}$ \\
\hline \multicolumn{5}{|l|}{ Lagged Median Voter * } \\
\hline Lagged Economic Globalization & & $\begin{array}{c}-0.003^{*} \\
(0.002)\end{array}$ & & $\begin{array}{l}-0.002 \\
(0.002)\end{array}$ \\
\hline$\rho$ Foreign Incumbent & $\begin{array}{c}0.007^{* * *} \\
(0.002)\end{array}$ & $\begin{array}{c}0.005^{* * *} \\
(0.001)\end{array}$ & & \\
\hline$\rho$ Foreign Incumbent: Same party group & & & $\begin{array}{c}0.005^{* * *} \\
(0.001)\end{array}$ & $\begin{array}{c}0.001^{* *} \\
(0.001)\end{array}$ \\
\hline Constant & $\begin{array}{c}5.497^{* * *} \\
(0.242)\end{array}$ & $\begin{array}{l}-0.757 \\
(0.770)\end{array}$ & $\begin{array}{c}5.950^{* * *} \\
(0.225)\end{array}$ & $\begin{array}{l}-0.169 \\
(0.756)\end{array}$ \\
\hline Party Fixed Effects & $\checkmark$ & $\checkmark$ & $\checkmark$ & $\checkmark$ \\
\hline Year Fixed Effects & $\checkmark$ & $\checkmark$ & $\checkmark$ & $\checkmark$ \\
\hline Observations & 2,718 & 2,718 & 2,718 & 2,718 \\
\hline Adjusted $\mathrm{R}^{2}$ & 0.685 & 0.894 & 0.687 & 0.893 \\
\hline F Statistic & $24.879^{* * *}$ & $91.808^{* * *}$ & $25.001^{* * *}$ & $91.338^{* * *}$ \\
\hline
\end{tabular}




\section{Interrupted Time Series Analysis}

To further examine our proposed mechanism of transnational party policy diffusion through EP party groups, we present results from an interrupted time series analysis in which we leverage the accession of Austria and Sweden to the EU (see Figure S4). Before the accession the Social Democratic Parties of the two countries were part of the Social Democratic Europarty but not the Social Democratic EP party group. Using the differences between the RILE position of the two Social Democratic parties and the lagged RILE position of the average foreign incumbent in the Social Democratic EP party group as dependent variable, we find negative slope and level changes in the post-accession period indicating that the two parties adjusted their position towards the foreign incumbents in the Social Democratic EP party group after becoming members of the EP party group. ${ }^{10}$ This provides evidence that learning and emulation of foreign incumbents is channeled through the EP party group.

Figure S 4: Regression Coefficients - Interrupted Time Series Model

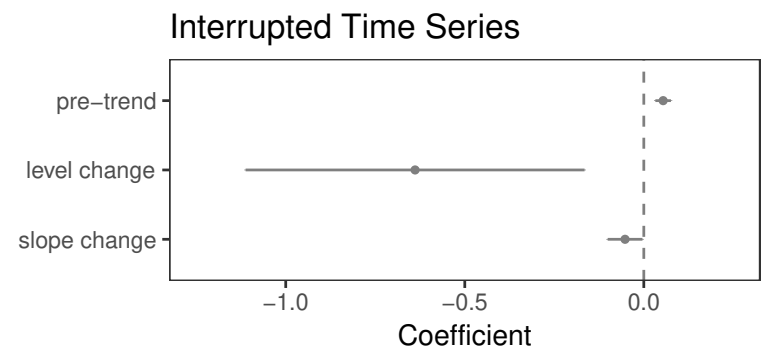

An ITS analysis uses data collected at equally spaced intervals before and after the occurrence of an event (i.e., becoming a member of a EP party group). The basic strategy of an ITS analysis is to use the observed trajectory of the outcome variable prior to the event to forecast the future trajectory of the outcome variable in the absent of the event. This assumed counterfactual is then used to estimate the causal effect of the event by comparing the assumed counterfactual with the observed outcome variable in the time period after the occurrence of the event.

A minimum of three variables is required for ITS analysis. First, the time $(T)$ elapsed since the start of the study. We use annual data for the 15 years before and after the Swedish and Austrian Social Democratic parties joined the Social Democratic party group in the EP. Second, a dummy variable indicating the pre-event period (coded 0 ) and the post-event period (coded 1). Third, the outcome variable at time $t$. Our outcome variable is the absolute distance between the RILE position of the two national Social Democratic parties and the average lagged RILE position of foreign incumbent in the Social Democratic EP group. We use a standard unadjusted ITS model considering both level and slope changes:

$$
Y_{t}=\beta_{0}+\beta_{1} T+\beta_{2} X_{t}+\beta_{3} T X_{t}
$$

where $\beta_{0}$ represent the baseline at $T=0, \beta_{1}$ is interpreted as the change in outcome associated with a time unit increase representing the underlying pre-event trend. $\beta_{2}$ is the level change following the event $(X=1)$ and $\beta_{3}$ indicates the slope change following the event (using the interaction between time and event: $T X)$. To make the model with interactions easier to interpret, we center the running variable $(T)$ by subtracting the cutoff point.

\section{Globalization and Political Parties}

In this section, we consider context-conditional responses to globalization (i.e., unit responses to exogenousexternal conditions may depend on unit characteristics). As suggested by Ward, Ezrow and Dorussen (2011),

\footnotetext{
${ }^{10}$ Please consult the Section 'Interrupted Time Series Analysis' in the appendix for more information.
} 
the effects of globalization should be stronger for Left parties than for Right parties. Below, we present model results that take such a context-conditional explanation into account. Our result on party policy diffusion within the same EP party group is robust to this alternative approach.

Table S 9: Single Spatial Lag Regression Models (S-OLS)

\begin{tabular}{|c|c|c|c|c|}
\hline & \multicolumn{4}{|c|}{ Dependent variable: RILE Party Position } \\
\hline & Model 1 & Model 2 & Model 3 & Model 4 \\
\hline Lagged RILE Party Position & $\begin{array}{l}1.021^{* * *} \\
(0.069)\end{array}$ & $\begin{array}{c}1.007^{* * *} \\
(0.069)\end{array}$ & $\begin{array}{c}1.008^{* * *} \\
(0.069)\end{array}$ & $\begin{array}{c}1.006^{* * *} \\
(0.069)\end{array}$ \\
\hline Lagged Median Voter & $\begin{array}{c}0.017 \\
(0.038)\end{array}$ & $\begin{array}{c}0.019 \\
(0.038)\end{array}$ & $\begin{array}{c}0.017 \\
(0.038)\end{array}$ & $\begin{array}{c}0.019 \\
(0.038)\end{array}$ \\
\hline Lagged Economic Globalization & $\begin{array}{c}0.017^{* * *} \\
(0.005)\end{array}$ & $\begin{array}{c}0.016^{* * *} \\
(0.005)\end{array}$ & $\begin{array}{c}0.015^{* * *} \\
(0.005)\end{array}$ & $\begin{array}{c}0.016^{* * *} \\
(0.005)\end{array}$ \\
\hline $\begin{array}{l}\text { Lagged RILE Party Position * } \\
\text { Lagged Economic Globalization }\end{array}$ & $\begin{array}{c}-0.003^{* * *} \\
(0.001)\end{array}$ & $\begin{array}{c}-0.003^{* * *} \\
(0.001)\end{array}$ & $\begin{array}{c}-0.003^{* * *} \\
(0.001)\end{array}$ & $\begin{array}{c}-0.003^{* * *} \\
(0.001)\end{array}$ \\
\hline$\rho$ Foreign Incumbent & $\begin{array}{c}0.004^{* * *} \\
(0.001)\end{array}$ & & & \\
\hline$\rho$ Foreign Incumbent: Same party group & & $\begin{array}{c}0.002^{* *} \\
(0.001)\end{array}$ & & $\begin{array}{c}0.002^{* *} \\
(0.001)\end{array}$ \\
\hline$\rho$ Foreign Incumbent: Different party group & & & $\begin{array}{c}0.0001 \\
(0.0003)\end{array}$ & $\begin{array}{c}0.0001 \\
(0.0003)\end{array}$ \\
\hline & $(0.001)$ & $(0.001)$ & $(0.001)$ & $(0.001)$ \\
\hline Constant & $\begin{array}{l}-0.547 \\
(0.460)\end{array}$ & $\begin{array}{l}-0.290 \\
(0.451)\end{array}$ & $\begin{array}{l}-0.265 \\
(0.452)\end{array}$ & $\begin{array}{l}-0.284 \\
(0.452)\end{array}$ \\
\hline Party Fixed Effects & $\checkmark$ & $\checkmark$ & $\checkmark$ & $\checkmark$ \\
\hline Year Fixed Effects & $\checkmark$ & $\checkmark$ & $\checkmark$ & $\checkmark$ \\
\hline Observations & 2,718 & 2,718 & 2,718 & 2,718 \\
\hline Adjusted $\mathrm{R}^{2}$ & 0.877 & 0.877 & 0.877 & 0.877 \\
\hline F Statistic & $77.937^{* * *}$ & $77.852^{* * *}$ & $77.636^{* * *}$ & $77.515^{* * *}$ \\
\hline
\end{tabular}

\section{EU, Migration, and RILE Disaggregation}

In the main section, we study party policy diffusion based on the RILE dimension. We focus on RILE because it constitutes the main cleavage between political parties across European democracies. However, one might be interested in the precise topics and strategies that are learned and emulated. For this reason, we present results based on individual manifesto categories. The first model shows that parties do not seem to learn from and emulate foreign incumbents Anti-EU position (per110 minus per108). We believe that the non-finding makes good sense. The EU is not important in national elections and parties do not win national elections because of their EU position. Second, we find no clear evidence that parties adjust their multiculturalism attitudes (per608 minus per607) towards the position of foreign incumbents from the same transnational party group. The category is used as a proxy for parties' migration attitudes. The coefficient is positive but small and not statistically significant at conventional levels. Given that migration has become increasingly important in national election campaigns, it seems reasonable that parties learn and emulate foreign incumbents' strategies. The sign of the coefficient points in this direction; however, it is difficult to capture parties' migration attitudes with manifesto data because the category includes migration-related multiculturalism but also concerns over national minorities.

Finally, we disaggregate the RILE dimension and find evidence that issues from the economic domain tend to be subject to party policy diffusion while issues from the political system domain are not. This 
suggests that political parties learn from and emulate cues about foreign incumbents' economic policies most strongly. We illustrate the findings by presenting results for the issues Political Authority, Free Market Economy, and Market Regulation which all three are part of the RILE measure (Model 3-5).

Table S 10: Single Spatial Lag Regression Models (S-OLS)

\begin{tabular}{|c|c|c|c|c|c|}
\hline & \multicolumn{5}{|c|}{ Dependent variables: } \\
\hline & $\begin{array}{c}\text { Anti-EU } \\
\text { (1) }\end{array}$ & $\begin{array}{l}\text { Anti-Multiculturalism } \\
\text { (2) }\end{array}$ & $\begin{array}{l}\text { Political Authority } \\
\text { (3) }\end{array}$ & $\begin{array}{l}\text { Free Market Economy } \\
\text { (4) }\end{array}$ & $\begin{array}{c}\text { Market Regulation } \\
\text { (5) }\end{array}$ \\
\hline Lagged Party Position & $\begin{array}{c}0.711^{* * *} \\
(0.014)\end{array}$ & $\begin{array}{c}0.683^{* * *} \\
(0.014)\end{array}$ & $\begin{array}{c}0.707^{* * *} \\
(0.013)\end{array}$ & $\begin{array}{c}0.667^{* * *} \\
(0.015)\end{array}$ & $\begin{array}{c}0.652^{* * *} \\
(0.014)\end{array}$ \\
\hline Lagged Median Voter & $\begin{array}{c}0.020 \\
(0.036)\end{array}$ & $\begin{array}{c}-0.053^{* *} \\
(0.021)\end{array}$ & $\begin{array}{c}0.137 \\
(0.137)\end{array}$ & $\begin{array}{c}0.057 \\
(0.053)\end{array}$ & $\begin{array}{c}0.104^{* *} \\
(0.049)\end{array}$ \\
\hline Lagged Economic Globalization & $\begin{array}{c}0.001 \\
(0.003)\end{array}$ & $\begin{array}{c}-0.003^{* *} \\
(0.001)\end{array}$ & $\begin{array}{l}0.0001 \\
(0.010)\end{array}$ & $\begin{array}{c}0.006 \\
(0.004)\end{array}$ & $\begin{array}{c}0.005 \\
(0.004)\end{array}$ \\
\hline \multicolumn{6}{|l|}{ Lagged Median Voter * } \\
\hline Lagged Economic Globalization & $\begin{array}{l}-0.0003 \\
(0.0005)\end{array}$ & $\begin{array}{l}0.001^{* * *} \\
(0.0003)\end{array}$ & $\begin{array}{l}-0.001 \\
(0.002)\end{array}$ & $\begin{array}{l}-0.001 \\
(0.001)\end{array}$ & $\begin{array}{c}-0.001^{* *} \\
(0.001)\end{array}$ \\
\hline$\rho$ Foreign Incumbent: Same party group & $\begin{array}{l}-0.0002 \\
(0.0002)\end{array}$ & $\begin{array}{c}0.0001 \\
(0.0001)\end{array}$ & $\begin{array}{l}0.0001 \\
(0.002)\end{array}$ & $\begin{array}{c}0.002 \\
(0.001)\end{array}$ & $\begin{array}{l}0.002^{* *} \\
(0.001)\end{array}$ \\
\hline Constant & $\begin{array}{l}1.507^{* * *} \\
(0.208)\end{array}$ & $\begin{array}{l}1.981^{* * *} \\
(0.138)\end{array}$ & $\begin{array}{l}-0.508 \\
(0.718)\end{array}$ & $\begin{array}{c}0.061 \\
(0.282)\end{array}$ & $\begin{array}{l}-0.060 \\
(0.258)\end{array}$ \\
\hline Observations & 2,599 & 2,599 & 2,599 & 2,599 & 2,599 \\
\hline Adjusted $\mathrm{R}^{2}$ & 0.756 & 0.754 & 0.771 & 0.780 & 0.705 \\
\hline Residual Std. Error & 0.075 & 0.043 & 0.281 & 0.111 & 0.101 \\
\hline F Statistic & $42.166^{* * *}$ & $41.563^{* * *}$ & $45.646^{* * *}$ & $47.877^{* * *}$ & $32.725^{* * *}$ \\
\hline
\end{tabular}

\section{Testing for remaining temporal correlation in residuals}

As described in the main text of the manuscript our choice to use a time-lagged spatial-lag model rests on the theoretical expectation that manifesto drafting processes are time-consuming and thus justify noninstantaneous interdependence. Moreover, we account for temporal dynamics (common trends) by adding a lagged dependent variable. When using such model specification, it is suggested to test whether the lagged dependent variable causes the remaining errors to be independent (Beck, Gleditsch and Beardsley, 2006; Franzese and Hays, 2008b). Below, we present tests for remaining temporal correlation of residuals for various model specifications (Models 1-4 from the main text). Model 1 (Foreign Incumbent) and Model 3 (Foreign Incumbent: Same EP party group) do not feature a lagged dependent variable. Model 2 (Foreign Incumbent) and Model 4 (Foreign Incumbent: Same EP party group) include a lagged dependent variable. While the residuals in Model 2 and Model 4 still exhibit some autocorrelation, it is clearly shown that our consideration of temporal dynamics mitigates the temporal correlation in residuals.

Table S 11: Breusch-Godfrey Test

\begin{tabular}{|c|c|c|c|}
\hline Model 1 & Model 2 & Model 3 & Model 4 \\
\hline 1307 & 10.938 & 1293.7 & 11.525 \\
\hline$p<0.01$ & $p<0.01$ & $p<0.01$ & $p<0.01$ \\
\hline
\end{tabular}


Figure S 5: Autocorrelation function (ACF)

Model 1

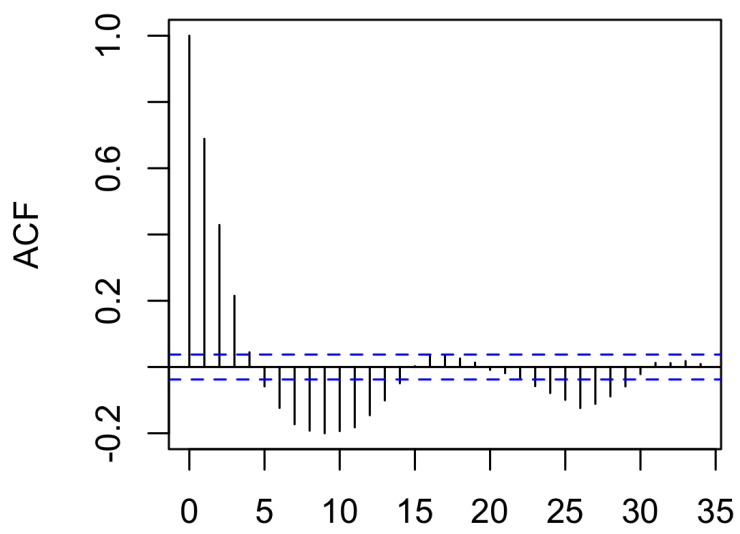

Lag

Model 3

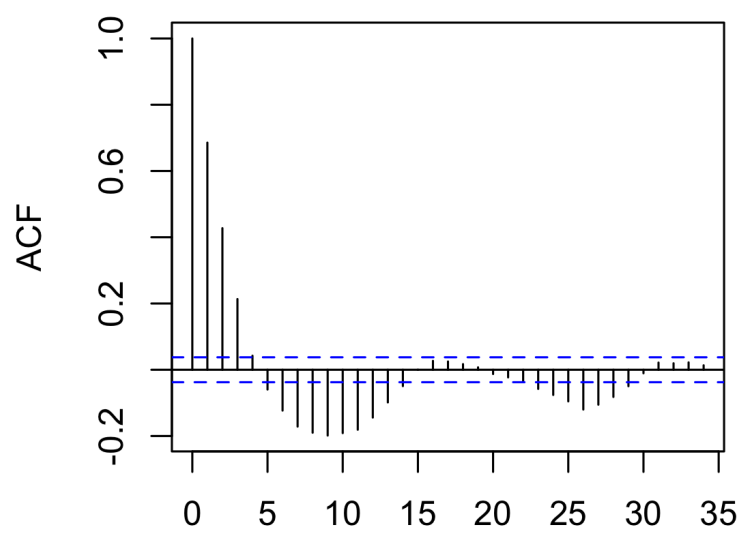

Lag

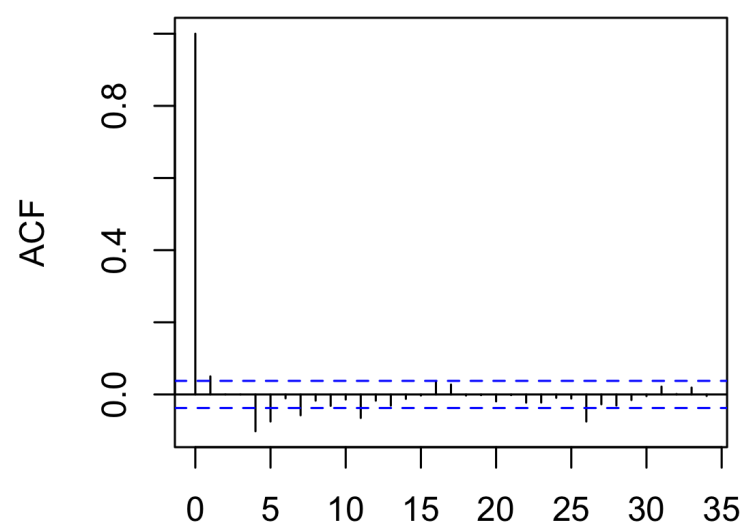

Lag

Model 2

Model 4

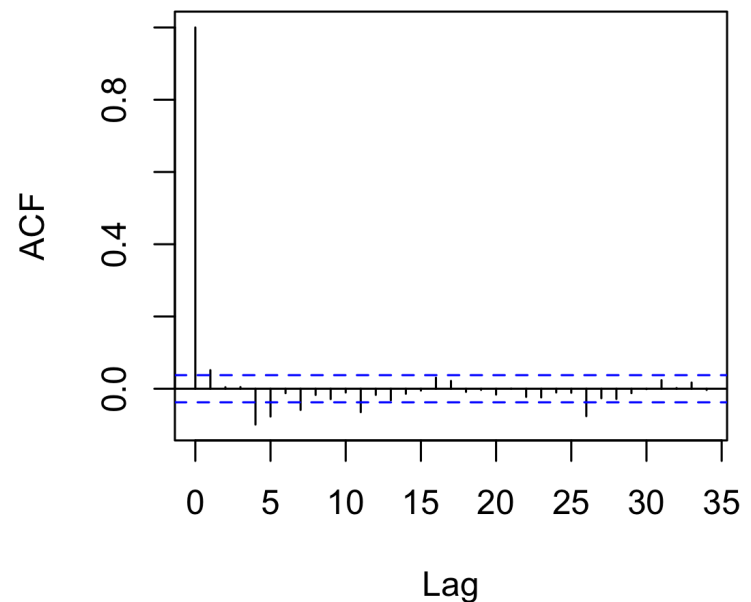

The remaining serial correlation in the residuals of our dynamic model indicate that the dynamic function has not been completely specified. One option is to consider additional lag terms (see Wooldridge 2002). Below, we present such an approach (by adding $t-2$ ) and show that serial correlation in the residuals is further reduced (Table S12) while our main conclusion is robust to this alternative specification (Table S13).

Table S 12: Breusch-Godfrey Test

\begin{tabular}{|c|c|}
\hline Model 2 (add. lag) & Model 4 (add. lag) \\
\hline 6.4555 & 6.0906 \\
\hline$p>0.01$ & $p>0.01$ \\
\hline
\end{tabular}


Table S 13: Single Spatial Lag Regression Models (S-OLS) with additional lag term

\begin{tabular}{|c|c|c|}
\hline & \multicolumn{2}{|c|}{ Dependent variable: } \\
\hline & \multicolumn{2}{|c|}{ RILE Party Position } \\
\hline & Model 2 (add. lag) & Model 4 (add. lag) \\
\hline Lagged RILE Party Position (t-1) & $\begin{array}{c}0.816^{* * *} \\
(0.019)\end{array}$ & $\begin{array}{c}0.816^{* * *} \\
(0.019)\end{array}$ \\
\hline Lagged RILE Party Position (t-2) & $\begin{array}{c}-0.087^{* * *} \\
(0.019)\end{array}$ & $\begin{array}{c}-0.088^{* * *} \\
(0.019)\end{array}$ \\
\hline Lagged Median Voter & $\begin{array}{c}0.533^{* * *} \\
(0.158)\end{array}$ & $\begin{array}{c}0.487^{* * *} \\
(0.157)\end{array}$ \\
\hline Lagged Economic Globalization & $\begin{array}{c}0.035^{* * *} \\
(0.011)\end{array}$ & $\begin{array}{c}0.031^{* * *} \\
(0.011)\end{array}$ \\
\hline Lagged Median Voter * & & \\
\hline Lagged Economic Globalization & $\begin{array}{c}-0.007^{* * *} \\
(0.002)\end{array}$ & $\begin{array}{c}-0.006^{* * *} \\
(0.002)\end{array}$ \\
\hline$\rho$ Foreign Incumbent & $\begin{array}{c}0.004^{* * *} \\
(0.001)\end{array}$ & \\
\hline$\rho$ Foreign Incumbent: Same party group & & $\begin{array}{l}0.002^{* *} \\
(0.001)\end{array}$ \\
\hline Constant & $\begin{array}{c}-1.615^{*} \\
(0.833)\end{array}$ & $\begin{array}{l}-1.177 \\
(0.816)\end{array}$ \\
\hline Party Fixed Effects & $\checkmark$ & $\checkmark$ \\
\hline Year Fixed Effects & $\checkmark$ & $\checkmark$ \\
\hline Observations & 2,718 & 2,718 \\
\hline $\mathrm{R}^{2}$ & 0.889 & 0.889 \\
\hline Adjusted $\mathrm{R}^{2}$ & 0.878 & 0.878 \\
\hline Residual Std. Error (df = 2464) & 0.323 & 0.323 \\
\hline F Statistic $(\mathrm{df}=253 ; 2464)$ & $78.135^{* * *}$ & $78.048^{* * *}$ \\
\hline
\end{tabular}




\section{Learning from and Emulating Opposition Parties}

Parties might not only respond to foreign incumbents (from the same EP party group) but also to foreign opposition parties that gained votes at the most recent election. To test the hypothesis, we use the spatial lag labelled $\rho$ Foreign Opposition (by vote gain). The connectivity matrix of this spatial lag is defined as follows: in the row corresponding to party $\mathrm{i}$, entries are 0 , unless in column $\mathrm{k}$ the corresponding party was recently in opposition in another country, in which case the entry is party k's absolute vote gain. The results do not provide evidence that a focal party is responsive to opposition parties when they gain votes in the previous election. This suggests that incumbency is the important cue that parties respond to.

Table S 14: Single Spatial Lag Regression Models (S-OLS)

\begin{tabular}{|c|c|c|}
\hline & \multicolumn{2}{|c|}{ Dependent variable: } \\
\hline & \multicolumn{2}{|c|}{ RILE Party Position } \\
\hline & Model OP1 & Model OP2 \\
\hline Lagged RILE Party Position & $\begin{array}{c}0.751^{* * *} \\
(0.013)\end{array}$ & $\begin{array}{c}0.752^{* * *} \\
(0.013)\end{array}$ \\
\hline Lagged Median Voter & $\begin{array}{c}0.416^{* * *} \\
(0.160)\end{array}$ & $\begin{array}{c}0.440^{* * *} \\
(0.158)\end{array}$ \\
\hline Lagged Economic Globalization & $\begin{array}{l}0.026^{* *} \\
(0.011)\end{array}$ & $\begin{array}{l}0.028^{* *} \\
(0.011)\end{array}$ \\
\hline Lagged Median Voter * & & \\
\hline Lagged Economic Globalization & $\begin{array}{c}-0.006^{* * *} \\
(0.002)\end{array}$ & $\begin{array}{c}-0.006^{* * *} \\
(0.002)\end{array}$ \\
\hline$\rho$ Foreign Opposition (by vote gain) & $\begin{array}{c}0.0002 \\
(0.0002)\end{array}$ & \\
\hline$\rho$ Foreign Opposition (by vote gain): Same party group & & $\begin{array}{l}-0.0001 \\
(0.0001)\end{array}$ \\
\hline Constant & $\begin{array}{l}-0.878 \\
(0.832)\end{array}$ & $\begin{array}{l}-1.030 \\
(0.820)\end{array}$ \\
\hline Observations & 2,718 & 2,718 \\
\hline $\mathrm{R}^{2}$ & 0.888 & 0.888 \\
\hline Adjusted $\mathrm{R}^{2}$ & 0.876 & 0.876 \\
\hline Residual Std. Error & 0.325 & 0.325 \\
\hline F Statistic & $77.437^{* * *}$ & $77.418^{* * *}$ \\
\hline
\end{tabular}




\section{F - Information about Political Parties}

Table S 15: National Parties and Political Groups at the EU level

\begin{tabular}{lccccc}
\hline$E P$ & MS & MS & Party Groups & Party Groups & No. of national parties \\
\hline EP I (79') & 9 & $\mathbf{9}$ & 7 & $\mathbf{7}$ & $\mathbf{4 9}$ \\
\hline EP II (84') & 10 & $\mathbf{1 0}$ & 8 & $\mathbf{7}$ & $\mathbf{5 6}$ \\
\hline EP III (89') & 12 & $\mathbf{1 2}$ & 10 & $\mathbf{1 0}$ & $\mathbf{6 8}$ \\
\hline EP IV (94') & 12 & $\mathbf{1 2}$ & 9 & $\mathbf{9}$ & $\mathbf{7 7}$ \\
\hline EP V (99') & 15 & $\mathbf{1 5}$ & 8 & $\mathbf{8}$ & $\mathbf{9 0}$ \\
\hline EP VI (04') & 25 & $\mathbf{2 1}$ & 7 & $\mathbf{7}$ & $\mathbf{9 7}$ \\
\hline EP VII (09') & 27 & $\mathbf{2 1}$ & 7 & $\mathbf{7}$ & $\mathbf{1 1 3}$ \\
\hline
\end{tabular}

Note: Numbers in plain font represent information from the European Parliamentary Research Service. Numbers in bold represent our data set. The number of parties gives the absolute number of parties that are included in our data per EP term.

\section{G - National parties included in empirical analysis}

$*=$ foreign incumbent

$E P=$ member of EP party group

()$=$ name of the EP party group

\section{Austria}

BZÖ Alliance for the Future of Austria (2007-2010)

FPÖ Austrian Freedom Party (1996-2010)*

GRÜNE The Greens (1996-2010) EP (Greens/EFA)

KPÖ Austrian Communist Party (2003-2010)

LIF Liberal Forum (1996-1998)

SPÖ Austrian Social Democratic Party (1996-2010) * EP (PES/S\&D)

ÖVP Austrian People's Party (1996-2010) * EP (EPP)

\section{Belgium}

AGALEV Live Differently (1982-2010) * EP (Greens/EFA)

CVP Christian People's Party (1977-2010) * EP (EPP)

ECOLO Ecologists (1982-2010) $* E P$ (Greens/EFA)

LDD List Dedecker (2008-2010) EP (ECR)

MR Reform Movement (2004-2010) EP (ELDR/ALDE)

PLDP Liberal Democratic and Pluralist Party (1977-1980)

PRL Liberal Reformation Party (1977-1994) *

PRL-FDF Liberal Reformation Party - Francophone Democratic Front (1996-1998)

PRL-FDF-MCC Liberal Reformation Party - Francophone Democratic Front - Citizens' Movement for Change (2000-2002)

PS Francophone Socialist Party (1979-2010) * EP (PES/S\&D) 
PSC Christian Social Party (1977-2010) * EP (EPP)

PVV Party of Liberty and Progress (1977-2010) * EP (ELDR/ALDE)

SP Flemish Socialist Party $(1977-2010) *$ EP (PES/S\&D)

SPIRIT Social, Progressive, International, Regionalist, Integrally Democratic and Forward-Looking (20082009) EP (PES/S\&D)

SPIRIT Socialist Party Different (2004-2009)

\section{Bulgaria}

ATAKA National Union Attack (2006-2008)

BSP Bulgarian Socialist Party (2006-2008)

DSB Democrats for a Strong Bulgaria (2006-2008) EP (EPP)

KzB Coalition for Bulgaria (2005-2008) EP (PES/S\&D)

NDSV National Movement Simeon the Second (2005-2008) * EP (ALDE)

ODS United Democratic Forces (2005-2008)

\section{Cyprus}

AKEL Progressive Party of the Working People (2005) EP (GUE)

DIKO Democratic Party (2005)*

DISY Democratic Coalition (2005) * EP (EPP)

KISOS Social Democrats' Movement (2005)*

\section{Czech Republic}

CSSD Czech Soc. Democratic Party (2005-2010) * EP (PES/S\&D)

KDU-CSL Christian and Democratic Union - Czech People's Party (2007-2010)

KDU-CSL-US-DEU Christian and Democratic Union - Czech People's Party - Freedom Union - Democratic Union $(2005) * E P($ EPP)

KSCM Communist Party of Bohemia and Moravia (2005-2010) EP (GUE/NGL)

ODS Civic Democratic Party (2005-2010) * EP (ECR)

SPR-RSC Association for the Republic - Republican Party of Czechoslovakia (2005)

SZ Green Party (2007-2010)

\section{Denmark}

CD Centre Democrats (1977-2006) * EP (EPP)

DF Danish People's Party (1999-2010) EP (UEN, European for Freedom and Democracy)

DKP Danish Communist Party (1977-1987)

EL Red-Green Unity List (1995-2010)

KF Conservative People's Party (1977-2006) * EP (EPP)

KrF Christian People's Party (1977-2006) *

NY New Alliance (2008-2010)

RV Radical Party (1977-2010) * EP (ELDR/ALDE)

SD Social Democratic Party (1977-2010) $*$ EP (PES/S\&D)

SF Socialist People's Party (1977-2010) EP (GUE/NGL, Greens/EFA, Communist Group, )

V Liberals (1977-2010) $*$ EP (ELDR/ALDE)

VS Left Socialist Party (1977-1986) 


\section{Estonia}

SDE Social Democratic Party EP (PES/S\&D)

EER Estonian Greens (2008-2010)

ER Estonian Reform Party (2005-2010) * EP (ELDR/ALDE)

IL Pro Patria Union (2005-2006) EP (EPP)

K Estonian Center Party (2005-2010) * EP (ELDR/ALDE)

M People's Party Moderates (2005-2010)

RP Union for the Republic (2005-2010)

\section{Finland}

KK National Coalition (1994-2010) * EP (EPP)

LKP Liberal People's Party (1994)

NSP Progressive Finnish Party, also known as Young Finns (1996-1998)

SKL Finnish Christian Union (1994-2010) * EP (EPP)

SSDP Finnish Social Democrats (1994-2010) * EP (PES/S\&D)

VAS Left Wing Alliance (1994-2010) $*$ EP (GUE/NGL)

VL Green Union (1994-2010) * EP (Greens/EFA)

\section{France}

CDP Centre, Democracy and Progress (1977)

CNIP National Centre of Independents and Peasants - Conservatives (1977-1992)

FN National Front (1987-2010) EP (European Right)

GE Ecology Generation (1977-2010)

Les Verts The Greens (1994-2010) * EP (Greens/EFA)

MR Reformers' Movement (1977)

PCF French Communist Party (1977-2010) * EP (GUE/NGL, Communist Group)

PS Socialist Party (1977-2010) * EP (PES/S\&D)

RPR Rally for the Republic - Gaullists (1977-2001)*

UDF Union for French Democracy (1979-2010) * EP (EPP, ALDE)

UMP Union for the Presidential Majority (2003-2010) EPP (EPP)

\section{Germany}

90/Greens Alliance‘90/Greens (1984-2010) * EP (Green/EFA)

CDU/CSU Christian Democratic Union/Christian Social Union (1977-2010) * EP (EPP)

FDP Free Democratic Party (1977-2010) * EP (ELDR/ALDE)

L-PDS The Left. Party of Democratic Socialism (2006-2008)

LINKE The Left (2010)

PDS Party of Democratic Socialism (1991-2004) EP (GUE/NGL)

SPD Social Democratic Party of Germany (1977-2010) * EP (PES/S\&D)

\section{Great Britain}

Conservative Party (1977-2010) * EP (EDG, EPP, ECR)

Labour Party (1977-2010) * EP (PES/S\&S)

Liberal Party (1977-2010) EP (ELDR/ALDE)

SDP Social Democratic Party (1984-1991)

SF Ourselves Alone (1998-2004) EP (GUE/NGL)

UUP Ulster Unionist Party (1993-2004) EP (EPP) 


\section{Greece}

DIKKI Democratic Social Movement (1997-1999) EP (GUE/NGL)

KKE Communist Party of Greece (1981-2006) EP (GUE/NGL)

ND New Democracy (1981-2007) $*$ EP (EPP)

PASOK Pan-Hellenic Socialist Movement (1981-2007) $*$ EP (PES/S\&D)

Pola Political Spring (1994-1999)

SYP Progressive Left Coalition (1990-2003)

SYRIZA Coalition of the Left, Movements and Ecology (2005-2006)

\section{Hungary}

FiDeSz-MPSz Federation of Young Democrats - Hungarian Civic Union (2005-2010) * EP (EPP)

FiDeSz-MPSz-KDNP Alliance of Federation of Young Democrats - Hungarian Civic Union - Christian Democratic People's Party (2007-2010)

MDF Hungarian Democratic Forum (2005-2009) EP (EPP)

MSzDP Hungarian Social Democratic Party (2007-2010)

MSzP Hungarian Socialist Party (2005-2010) * EP (PES/S\&D)

SzDSz Alliance of Free Democrats (2005-2009) * EP (ELDR/ALDE)

\section{Ireland}

DLP Democratic Left Party (1993-2001)

Family of the Irish (1977-2010) * EP (EPP)

Green Party (1990-2010) EP (Greens/EFA)

Labour Party (1997-2010) * EP (PES/S\&D)

PD Progressive Democrats (1988-2010) $* E P$ (ELDR/ALDE)

Soldiers of Destiny (1977-2010) * EPP (EDA, UEN, ELDR/ALDE)

WP Workers' Party (1982-1992)

\section{Italy}

AD Democratic Alliance (1995-2000)

AN National Alliance (1994-2007) $* E P($ UEN)

CCD Christian Democratic Centre (1997-2000)*

DC Christian Democrats (1977-2000) * EP (EPP)

DP Proletarian Democracy (1984-1991)

FI Go Italy (1995-2007) * EP (EPP)

FdV Green Federation (1988-2007)

House of Freedom (2002-2005)

IdV List Di Pietro - Italy of Values (2002-2010) * EP (ELDR/ALDE)

LN Northern League (1993-2010) EP (Democracy Group, EFD)

M-DL Daisy Democracy is Freedom (2002-2005)

MSI-DN Italian Social Movement-National Right (1977-2007)

NPSI New Italian Socialist Party (2002-2007)

Olive Tree (2002-2007) EP (PES/S\&D)

PCI Italian Communist Party (1977-2005) * EP (GUE/NGL, PES/S\&D)

PD Democratic Party (2009-2010) EP (PES/S\&D)

PI Pact for Italy (1995)

PLI Italian Liberal Party (1977-1993)* 
PR Radical Party (1977-2000)

PRC Communist Refoundation Party (1993-2007) EP (GUE/NGL)

PRI Italian Republican Party (1977-1993)*

PSDI Italian Democratic Socialist Party (1977-1993)*

PSI Italian Socialist Party (1977-1995)*

PdCI Party of Italian Communists (2002-2007) * EP (GUE/NGL)

PdL People of Freedom (2009-2010)

PdUP Proletarian Unity Party for Communism (The Manifesto/Proletarian Unity Party) (1977-1986)

RI Italian Renewal (1977-2000)

RnP Rose in the Fist (2007)

The Girasole (Sunflower) (2002-2005)

UdC Union of the Center (2007-2010) EP (EPP)

White Flower (2002-2005)

\section{Latvia}

JL New Era (2005)

LC Latvian Way Union (2005) *

LPP Latvia's First Party (2005)

PCTVL For Human Rights in a United Latvia (2005)

TB-LNNK For Fatherland and Freedom - Latvian National Independence Movement (2005) *

TP People's Party (2005) *

\section{Luxembourg}

CSV/PCS Christian Social People's Party (1977-2010) * EP (EPP)

DP/PD Democratic Party (1977-2010) * EP (ELDR/ALDE)

GAP Green Alternative (1985-1993)

GLEI Green Left Ecological Initiative (1990-1993)

GLEI-GAP Green Left Ecological Initiative - Green Alternative (1995-2003) EP (Greens/EFA)

KPL/PCL Communist Party (1977- 1993)

LSAP/POSL Socialist Workers' Party (1977-2010) * EP (PES/S\&D)

The Greens (2005-2010)

The Left (2010)

\section{Netherlands}

CDA Christian Democratic Appeal (1978-2010) * EP (EPP)

CU Christian Union (2003-2010)

DS'70 Democratic Socialists'70 (1977- 1980)

D'66 Democrats'66 (1977-2010) * EP (ELDR/ALDE)

GL Green Left (1990-2010) EP (Greens/EFA)

LN Livable Netherlands (2003-2005)

LPF List Pim Fortuyn (2003-2005)

PPR Radical Political Party (1977-1988)*

PVV Party of Freedom (2007-2010)

PvdA Labour Party (1977-2010) * EP (PES/S\&D)

SP Socialist Party (1995-2010) EP (GUE/NGL)

VVD People's Party for Freedom and Democracy (1977-2010) * EP (ELDR(ALDE) 


\section{Norway}

DnA Norwegian Labour Party (1991-2006)*

H Conservative Party (1991-2006)*

KrF Christian People's Party (1991-2006)*

SV Socialist Left Party (1991-2006)

V Liberal Party (1991-2006)*

\section{Poland}

LPR League of Polish Families (2005-2006)

PO Civic Platform (2005-2010) EP (EPP)

PiS Law and Justice (2005-2010) * EP (ECR)

SLD Democratic Left Alliance (2006) *

\section{Portugal}

BE Left Bloc (2000-2010) EP (GUE/NGL)

CDS Social Democratic Center Party (1986-2010) EP (EPP, UEN)

CDU Unified Democratic Coalition (1992-2008) EP (GUE/NGL)

ID Democratic Intervention (1988-1990)

MDP Popular Democratic Movement (1986)

PCP Portuguese Communist Party (1986-2010) EP (GUE/NGL)

PEV Ecologist Party 'The Greens' (1986-2010)

PRD Democratic Renewal Party (1986-1990)

PS Socialist Party $(1986-2010) * E P(\mathrm{PES} / \mathrm{S} \& \mathrm{D})$

PSD Social Democratic Party (1986-2010) * EP (ALDE, EPP)

UDP Popular Democratic Union (1986-1990)

\section{Romania}

PDL Democratic Liberal Party (2009-2010) EP (EPP)

PNL National Liberal Party (2009-2010) * EP (ELDR/ALDE)

\section{Slovakia}

ANO Alliance of the New Citizen (2005)

HZDS Movement for a Democratic Slovakia (2005-2010) *

KDH Christian Democratic Movement (2005-2010) * EP (EPP)

KSS Communist Party of Slovakia (2005)

SDKÚ-DS Slovak Democratic and Christian Union - Democratic Party (2005-2010) * EP (EPP)

SDL' Party of the Democratic Left (2005)*

SNS Slovak National Party (2007-2010) * EP (EFD)

Smer Direction-Social Democracy (2005-2010) * EP (PES/S\&D)

\section{Slovenia}

For Real (2009-2010) EP (ELDR/ALDE)

LDS Liberal Democracy of Slovenia (2005-2010) EP (ELDR/ALDE)

Nsi New Slovenian Christian People's Party (2005-2010) * EP (EPP)

SD Social Democratic Party (2005-2010) EP (PES/S\&D) 
SDS Slovenian Democratic Party (2005-2010) EP (EPP)

SLS Slovenian People's Party (2005-2010)*

SNS Slovenian National Party (2005-2010)

\section{Spain}

CDS Centre Democrats (1986-1995)

CiU Convergence and Union (1986-2010) EP (ELDR/ALDE)

IU United Left (1986-2010) EP (GUE/NGL)

PDP Popular Democratic Party (1986-1988)

PL Liberal Party (1987-1988)

PP Popular Party (1986-2010) * EP (EPP)

PSOE Spanish Socialist Workers' Party (1986-2010) * EP (PES/S\&D)

\section{Sweden}

FP People's Party (1996-2010) * EP (ELDR/ALDE)

Kd Christian Democrats (1996-2010) * EP (EPP)

MP Green Ecology Party (1996-2010) EP (Greens/EFA)

MSP Moderate Coalition Party (1996-2010) * EP (EPP)

SAP Social Democratic Labor Party (1996-2010) * EP (PES/S\&D)

VPK Left Communists Party (1996-2010) EP (GUE/NGL) 